\title{
Simulation of Streamflow in the Pleasant, Narraguagus, Sheepscot, and Royal Rivers, Maine, using Watershed Models
}

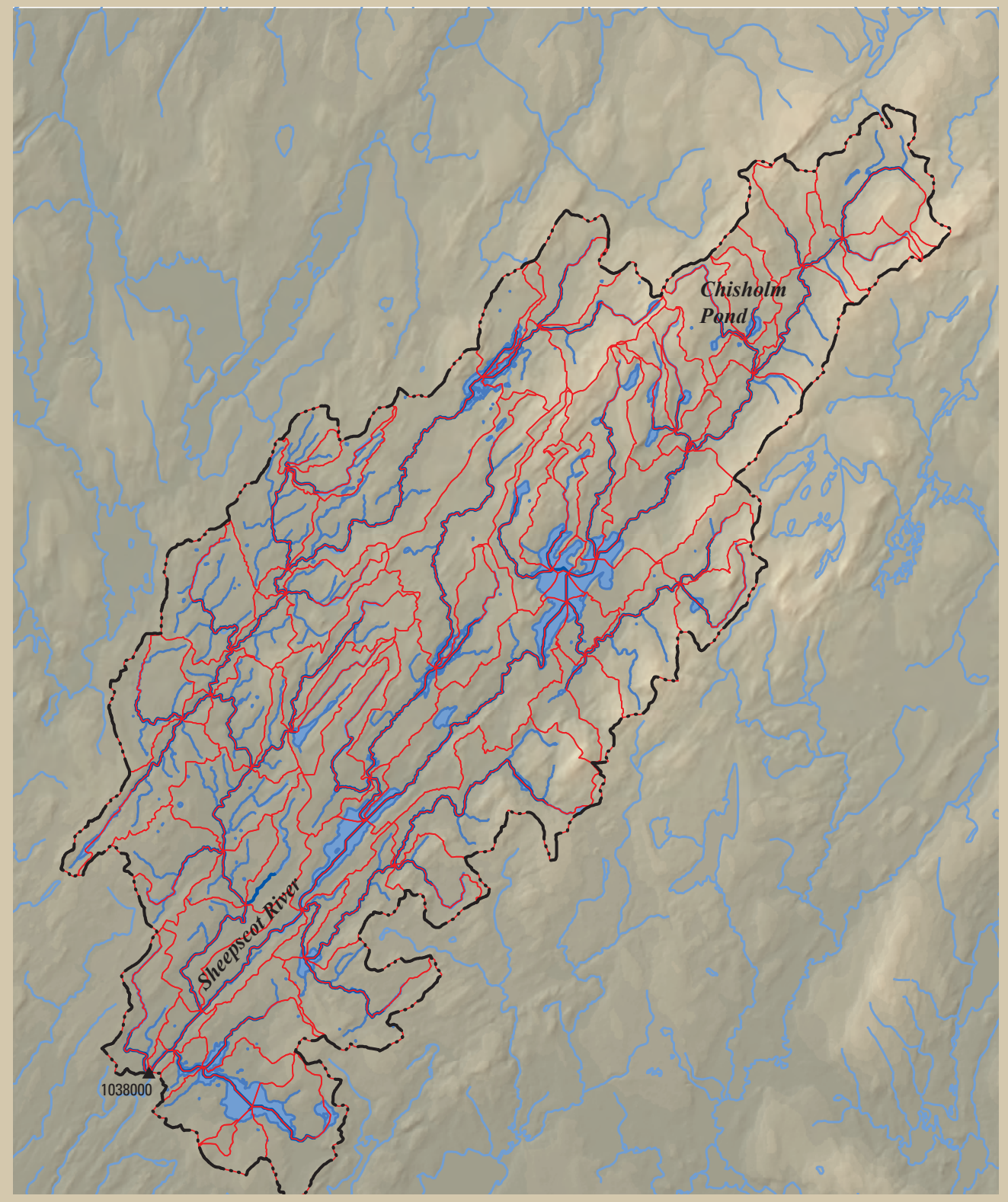

Scientific Investigations Report 2010-5221 
Cover. Illustration shows watershed model area, stream network, and model response unit boundaries for the Sheepscot River, Maine. 


\section{Simulation of Streamflow in the Pleasant, Narraguagus, Sheepscot, and Royal Rivers, Maine, using Watershed Models}

By Robert W. Dudley and Martha G. Nielsen

Scientific Investigations Report 2010-5221 


\section{U.S. Department of the Interior \\ KEN SALAZAR, Secretary \\ U.S. Geological Survey \\ Marcia K. McNutt, Director}

U.S. Geological Survey, Reston, Virginia: 2011

For more information on the USGS - the Federal source for science about the Earth, its natural and living resources, natural hazards, and the environment, visit http://www.usgs.gov or call 1-888-ASK-USGS

For an overview of USGS information products, including maps, imagery, and publications, visit http://www.usgs.gov/pubprod

To order this and other USGS information products, visit http://store.usgs.gov

Any use of trade, product, or firm names is for descriptive purposes only and does not imply endorsement by the U.S. Government.

Although this report is in the public domain, permission must be secured from the individual copyright owners to reproduce any copyrighted materials contained within this report.

Suggested citation:

Dudley, R.W., and Nielsen, M.G., 2011, Simulation of streamflow in the Pleasant, Narraguagus, Sheepscot, and Royal Rivers, Maine, using watershed models: U.S. Geological Survey Scientific Investigations Report 2010-5221, 31 p., at http://pubs.usgs.gov/sir/2010/5221/. 


\section{Contents}

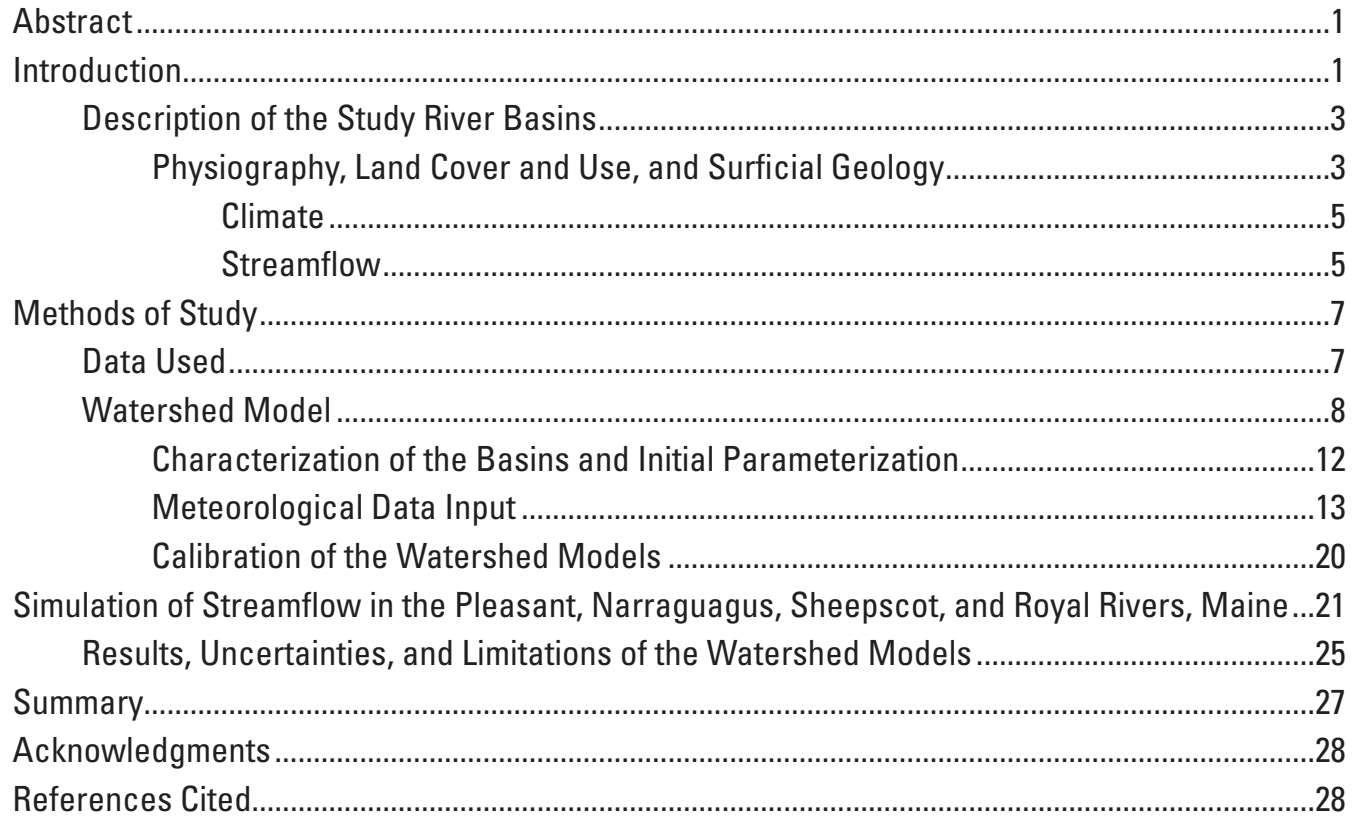

\section{Figures}

1-3. Maps showing-

1. Location of selected Atlantic salmon rivers in coastal Maine.

2. The study basins for the Pleasant, Narraguagus, Sheepscot, and Royal Rivers, Maine

3. Network of Maine meteorological stations supplying precipitation and air temperature data used in this investigation.....

4. Graph showing median monthly streamflows measured at U.S. Geological Survey streamgages on the Pleasant (01022260), Narraguagus (01022500), Sheepscot (01038000), and Royal Rivers (01060000), Maine.

5. Schematic diagram of the operational design of the Precipitation Runoff Modeling System (PRMS)

6. Maps showing Model Response Units and drainage networks for the watershed models of the $(A)$ Pleasant, $(B)$ Narraguagus, $(C)$ Sheepscot, and $(D)$ Royal Rivers.......14

7-10. Graphs showing-

7. Solar radiation data for (A) Pleasant River Basin, $(B)$ Narraguagus River Basin, (C) Sheepscot River Basin, and (D) Royal River Basin.

8. Potential evapotranspiration data for (A) Pleasant River Basin, $(B)$ Narraguagus River Basin, (C) Sheepscot River Basin, and for (D) Royal River Basin. 
9. (A) Pleasant River Basin calibrated model output for mean seasonal and annual outflow volumes simulating the measured period from August 1, 1980, through September 30, 1991; (B) Pleasant River Basin evaluation model output simulating the measured period from October 1, 2000, through September 30, 2007; (C) Narraguagus River Basin calibrated model output for mean seasonal and annual outflow volumes simulating the measured period from August 1, 1980, through September 30, 1997; (D) Narraguagus River Basin evaluation model output simulating the measured period from October 1, 1997, through September 30, 2007; (E) Sheepscot River Basin calibrated model output for mean seasonal and annual outflow volumes simulating the measured period from August 1, 1980, through September 30, 1997; (F) Sheepscot River Basin evaluation model output simulating the measured period from October 1, 1997, through September 30, 2007; (G) Royal River Basin calibrated model output for mean seasonal and annual outflow volumes simulating the measured period from August 1, 1980, through September 30, 1997; and (H) Royal River Basin evaluation model output simulating the measured period from October 1, 1997, through September 30, 2004. .24

10. Calibration and evaluation model output for all daily streamflow for the Pleasant River Basin $(A, B)$, Narraguagus River Basin $(C, D)$, Sheepscot River Basin $(E, F)$, and Royal River Basin $(G, H)$.

\section{Tables}

1. U.S. Geological Survey streamgages used in this study, coastal Maine.

2. National Oceanic and Atmospheric Administration's National Weather Service Cooperative Observer Program meteorological stations used in this investigation in the vicinity of the coastal study basins, Maine

3. Modular Modeling System (MMS) Modules used in the Precipitation-Runoff Modeling System for this investigation.

4. Model Response Units (MRUs) per study basin, ranges of size, and mean size, Maine

5. Sources of values for selected Model Response Unit (MRU) (distributed) and wholemodel (nondistributed) Precipitation Runoff Modeling System (PRMS) parameters for the study basins, Maine.

6. Meteorological stations (National Oceanic and Atmospheric Administration's National Weather Service Cooperative Observer Program (NOAA COOP)) in the vicinity of the study basins from whose meteorological data (precipitation and maximum and minimum air temperature) multiple linear regressions (MLR) were derived to be spatially distributed within each study basin

7. Interquartile ranges (IOR) defining the threshold streamflow values delineating low (below the IQR), high (above the IQR), and intermediate (within the IQR, inclusive) streamflow regimes for each study basin

8. Nash-Sutcliffe efficiency (NSE) statistics for calibration and evaluation model runs for each study basin, coastal Maine..... 


\section{Conversion Factors and Datum}

Inch/Pound to SI

\begin{tabular}{|c|c|c|}
\hline Multiply & By & To obtain \\
\hline \multicolumn{3}{|c|}{ Length } \\
\hline inch (in.) & 2.54 & centimeter $(\mathrm{cm})$ \\
\hline inch (in.) & 25.4 & millimeter $(\mathrm{mm})$ \\
\hline foot $(\mathrm{ft})$ & 0.3048 & meter $(\mathrm{m})$ \\
\hline mile (mi) & 1.609 & kilometer $(\mathrm{km})$ \\
\hline \multicolumn{3}{|c|}{ Area } \\
\hline square mile $\left(\mathrm{mi}^{2}\right)$ & 259.0 & hectare (ha) \\
\hline square mile $\left(\mathrm{mi}^{2}\right)$ & 2.590 & square kilometer $\left(\mathrm{km}^{2}\right)$ \\
\hline \multicolumn{3}{|c|}{ Volume } \\
\hline cubic foot $\left(\mathrm{ft}^{3}\right)$ & 28.32 & cubic decimeter $\left(\mathrm{dm}^{3}\right)$ \\
\hline cubic foot $\left(\mathrm{ft}^{3}\right)$ & 0.02832 & cubic meter $\left(\mathrm{m}^{3}\right)$ \\
\hline \multicolumn{3}{|c|}{ Flow rate } \\
\hline foot per second (ft/s) & 0.3048 & meter per second $(\mathrm{m} / \mathrm{s})$ \\
\hline cubic foot per second $\left(\mathrm{ft}^{3} / \mathrm{s}\right)$ & 0.02832 & cubic meter per second $\left(\mathrm{m}^{3} / \mathrm{s}\right)$ \\
\hline $\begin{array}{l}\text { cubic foot per second per square } \\
\text { mile }\left[\left(\mathrm{ft}^{3} / \mathrm{s}\right) / \mathrm{mi}^{2}\right]\end{array}$ & 0.01093 & $\begin{array}{l}\text { cubic meter per second per square } \\
\text { kilometer }\left[\left(\mathrm{m}^{3} / \mathrm{s}\right) / \mathrm{km}^{2}\right]\end{array}$ \\
\hline million gallons per day (Mgal/d) & 0.04381 & cubic meter per second $\left(\mathrm{m}^{3} / \mathrm{s}\right)$ \\
\hline $\begin{array}{l}\text { million gallons per day per square } \\
\text { mile }\left[(\mathrm{Mgal} / \mathrm{d}) / \mathrm{mi}^{2}\right]\end{array}$ & 1,461 & $\begin{array}{l}\text { cubic meter per day per square } \\
\text { kilometer }\left[\left(\mathrm{m}^{3} / \mathrm{d}\right) / \mathrm{km}^{2}\right]\end{array}$ \\
\hline \multicolumn{3}{|c|}{ Hydraulic conductivity } \\
\hline foot per day (ft/d) & 0.3048 & meter per day $(\mathrm{m} / \mathrm{d})$ \\
\hline \multicolumn{3}{|c|}{ Transmissivity* } \\
\hline foot squared per day $\left(\mathrm{ft}^{2} / \mathrm{d}\right)$ & 0.09290 & meter squared per day $\left(\mathrm{m}^{2} / \mathrm{d}\right)$ \\
\hline
\end{tabular}

Temperature in degrees Celsius $\left({ }^{\circ} \mathrm{C}\right)$ may be converted to degrees Fahrenheit $\left({ }^{\circ} \mathrm{F}\right)$ as follows:

$$
{ }^{\circ} \mathrm{F}=\left(1.8 \times{ }^{\circ} \mathrm{C}\right)+32
$$

Temperature in degrees Fahrenheit $\left({ }^{\circ} \mathrm{F}\right)$ may be converted to degrees Celsius $\left({ }^{\circ} \mathrm{C}\right)$ as follows:

$$
{ }^{\circ} \mathrm{C}=\left({ }^{\circ} \mathrm{F}-32\right) / 1.8
$$

Vertical coordinate information is referenced to the North American Vertical Datum of 1988 (NAVD 88).

Horizontal coordinate information is referenced to the North American Datum of 1983 (NAD 83). Altitude, as used in this report, refers to distance above the vertical datum. 
THIS PAGE INTENTIONALLY LEFT BLANK 


\title{
Simulation of Streamflow in the Pleasant, Narraguagus, Sheepscot, and Royal Rivers, Maine, using Watershed Models
}

\author{
By Robert W. Dudley and Martha G. Nielsen
}

\begin{abstract}
The U.S. Geological Survey (USGS) began a study in 2008 to investigate anticipated changes in summer streamflows and stream temperatures in four coastal Maine river basins and the potential effects of those changes on populations of endangered Atlantic salmon. To achieve this purpose, it was necessary to characterize the quantity and timing of streamflow in these rivers by developing and evaluating a distributed-parameter watershed model for a part of each river basin by using the USGS Precipitation-Runoff Modeling System (PRMS). The GIS (geographic information system) Weasel, a USGS software application, was used to delineate the four study basins and their many subbasins, and to derive parameters for their geographic features. The models were calibrated using a four-step optimization procedure in which model output was evaluated against four datasets for calibrating solar radiation, potential evapotranspiration, annual and seasonal water balances, and daily streamflows. The calibration procedure involved thousands of model runs that used the USGS software application Luca (Let us calibrate). Luca uses the Shuffled Complex Evolution (SCE) global search algorithm to calibrate the model parameters. The calibrated watershed models performed satisfactorily, in that Nash-Sutcliffe efficiency (NSE) statistic values for the calibration periods ranged from 0.59 to 0.75 (on a scale of negative infinity to 1) and NSE statistic values for the evaluation periods ranged from 0.55 to 0.73 .

The calibrated watershed models simulate daily streamflow at many locations in each study basin. These models enable natural resources managers to characterize the timing and amount of streamflow in order to support a variety of water-resources efforts including water-quality calculations, assessments of water use, modeling of population dynamics and migration of Atlantic salmon, modeling and assessment of habitat, and simulation of anticipated changes to streamflow and water temperature resulting from changes forecast for air temperature and precipitation.
\end{abstract}

\section{Introduction}

The Gulf of Maine Distinct Population Segment (GOM DPS) of Atlantic salmon (Salmo salar) was classified as endangered, and therefore protected, under the Federal Endangered Species Act (ESA) in November 2007. In June 2009 , the geographic scope of the listing was expanded to include larger river systems; at present, the listing incorporates historically accessible freshwater habitat between the Androscoggin and Dennys Rivers, inclusive (fig. 1) (National Oceanic and Atmospheric Administration, 2009). All waters designated in the associated critical habitat drain to the Gulf of Maine. The proximity of these waters to the southern extent of the Atlantic salmon's geographical range makes these populations potentially sensitive to changes in climate. State and Federal fisheries biologists are concerned about past, current, and future influences of changing climate and varying hydrologic conditions on the survival of Atlantic salmon in these rivers.

Recent studies have demonstrated strong evidence of hydrologic changes during the last 30 to 150 years in the northeastern United States. These changes, which are consistent with warming air temperatures during winter through spring, include significant changes in snowmelt runoff earlier each spring; decreasing duration of ice on rivers and lakes; decreasing ratio of snowfall to total precipitation; and denser and thinner late-winter snowpack (Hodgkins and Dudley, 2006a, 2006b; Hodgkins and others, 2005; Huntington and others, 2004; Hodgkins and others, 2002; Dudley and Hodgkins, 2002). The combined area Maine, New Hampshire, Vermont, and the Canadian province of New Brunswick exhibit the strongest and most consistent changes and drains into the Gulf of Maine. Projections from climate models for the northeastern United States indicate air-temperature warming, earlier snowmelt runoff, increases in annual evaporation, and decreased low streamflows for the future (Hayhoe and others, 2007). These "model projections" are herein termed projected changes. 


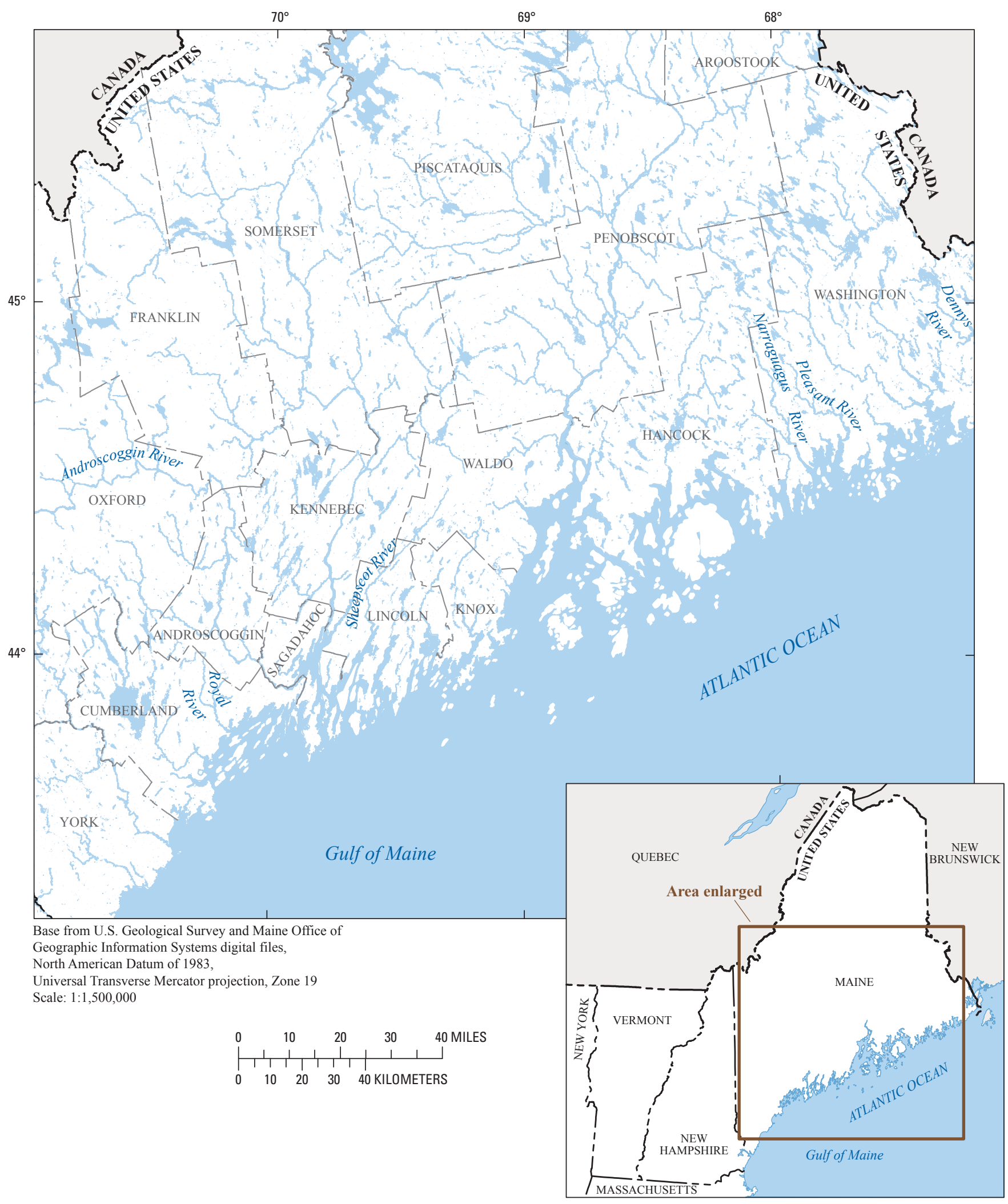

LOCATION MAP

Figure 1. Location of selected Atlantic salmon rivers in coastal Maine. 
The Pleasant, Narraguagus, Sheepscot, and Royal Rivers (fig. 1) provide important habitat for wild Atlantic salmon. A comprehensive recovery program has been designed to protect and recover the species so that it can remain viable with minimal ongoing management and investment of resources (National Marine Fisheries Service and U.S. Fish and Wildlife Service, 2004). In 1997, the State of Maine developed conservation plans, updated in 2005, for these Atlantic salmon rivers in Maine (the Pleasant, Narraguagus, Sheepscot, and Royal Rivers, among others) (Maine Atlantic Salmon Task Force, 1997; Maine Atlantic Salmon Commission, 2005). In 2008, the USGS, through its National Climate Change and Wildlife Science Center, began a study of anticipated changes in summer streamflows and stream temperatures and the potential effects of such changes on endangered Atlantic salmon populations (Dudley and others, 2008). To characterize the amount and timing of streamflow in these rivers, the study developed a distributed-parameter watershed model for each river basin. These watershed models could, in turn, support follow-on modeling of the effects of climate change on basin hydrology. Modeled streamflow output also could provide input to survival models for Atlantic salmon populations. This report documents the construction, calibration, and evaluation of distributed-parameter watershed models for parts of the Pleasant, Narraguagus, Sheepscot, and Royal River Basins that can inform subsequent survival modeling of Atlantic salmon.

Calibrated watershed models of the study basins provide simulated daily streamflow time series for many subbasin locations through each basin. This enables managers of natural resources to characterize the timing and quantity of water moving through each basin to support a variety of water-resources efforts, including water-quality calculations (for example, Ahearn and others, 2005), assessments of wateruse, modeling of Atlantic salmon population dynamics and migration, modeling and assessment of habitat, and testing scenarios - such as changes to streamflows and water temperature that are anticipated to result from forecasted changes in climate. Calibrated models representative of current conditions can be used to simulate future traces of streamflow driven by downscaled global climate model information. In this manner, the watershed models can be used to output an ensemble of future streamflow hydrographs representing a range of emissions scenarios simulated by several different global climate models. This methodology is currently (2010) being used to investigate anticipated changes in summer streamflows and stream temperatures and the potential effects of those changes on endangered Atlantic salmon populations.

\section{Description of the Study River Basins}

The basins of the four coastal rivers were chosen for study because the rivers are home to Atlantic salmon, have minimal or no regulation of streamflows, and have at least 15 years of continuous streamgage data. The study basins (fig. 2) are representative of the geographic and climatic variability of coastal Maine: the Pleasant and Narraguagus River Basins are in the eastern coastal climate-response region, and the Sheepscot and Royal River Basins are in the southern coastal climate-response region as defined by the framework for a USGS hydrologic climate-response network in Maine (Hodgkins and others, 2009). PRMS models were developed for the area draining to a USGS streamgage station in each of the four basins.

Draining an area of 126 square miles $\left(\mathrm{mi}^{2}\right)$ (Fontaine, 1982a), the Pleasant River flows predominantly northwest to southeast from its headwaters near Pleasant River Lake (altitude, 317 feet (ft)), through a bog named Great Heath $\left(7 \mathrm{mi}^{2}\right)$ in the middle of the basin, to the Atlantic Ocean in the Gulf of Maine. The USGS streamgage 01022260 (altitude, $127 \mathrm{ft}$ ) on the main stem of the Pleasant River near Epping streamgage is about 12 mi upstream from the mouth of the river and it gages streamflow from a $60.6-\mathrm{mi}^{2}$ drainage area at the outlet of the Great Heath (Fontaine, 1982a). The Pleasant and Narraguagus River Basins share a watershed boundary along the western perimeter of the Pleasant River Basin.

The Narraguagus River drains an area of $243 \mathrm{mi}^{2}$ (Fontaine, 1982a) and flows predominantly northwest to southeast from Eagle Lake (altitude, $406 \mathrm{ft}$ ) to the Atlantic Ocean in the Gulf of Maine (Fontaine, 1982a). The USGS streamgage 01022500 (altitude $44 \mathrm{ft}$ ) on the main stem of the Narraguagus River at Cherryfield is about $6 \mathrm{mi}$ upstream from the mouth of the river and it gages streamflow from a $227-\mathrm{mi}^{2}$ drainage area.

The Sheepscot River drains an area of $350 \mathrm{mi}^{2}$ (Fontaine, 1982b) and flows predominantly northeast to southwest from its headwater near Chisolm Pond (altitude, $348 \mathrm{ft}$ ) to the Atlantic Ocean in the Gulf of Maine. The USGS streamgage 01038000 (altitude $101 \mathrm{ft}$ ) on the main stem of the Sheepscot River at North Whitefield is about $21 \mathrm{mi}$ upstream from the mouth of the river, and it gages streamflow from a $145-\mathrm{mi}^{2}$ drainage area (Fontaine, 1982b).

The Royal River drains an area of $143 \mathrm{mi}^{2}$ (Fontaine, 1978) and flows predominantly north to south from headwaters near Sabbathday Lake (altitude, $299 \mathrm{ft}$ ) to the Atlantic Ocean in the Gulf of Maine. The discontinued USGS streamgage 01060000 (altitude $10 \mathrm{ft}$ ) on the main stem of the Royal River at Yarmouth was less than 2 mi upstream from the mouth of the river, gaging streamflow from a drainage area of $141 \mathrm{mi}^{2}$ (Fontaine, 1978).

\section{Physiography, Land Cover and Use, and Surficial Geology}

Rolling topography with little development characterizes the parts of the study basins included in the watershed models. The peak altitudes in the hilly topography of the basins range from about $610 \mathrm{ft}$ in the Royal River Basin and 1,100 ft in the Sheepscot River Basin to about 1,450 ft along the basin boundaries of the Pleasant and Narraguagus Rivers. Landcover data for Maine derived from Landsat Thematic Mapper 


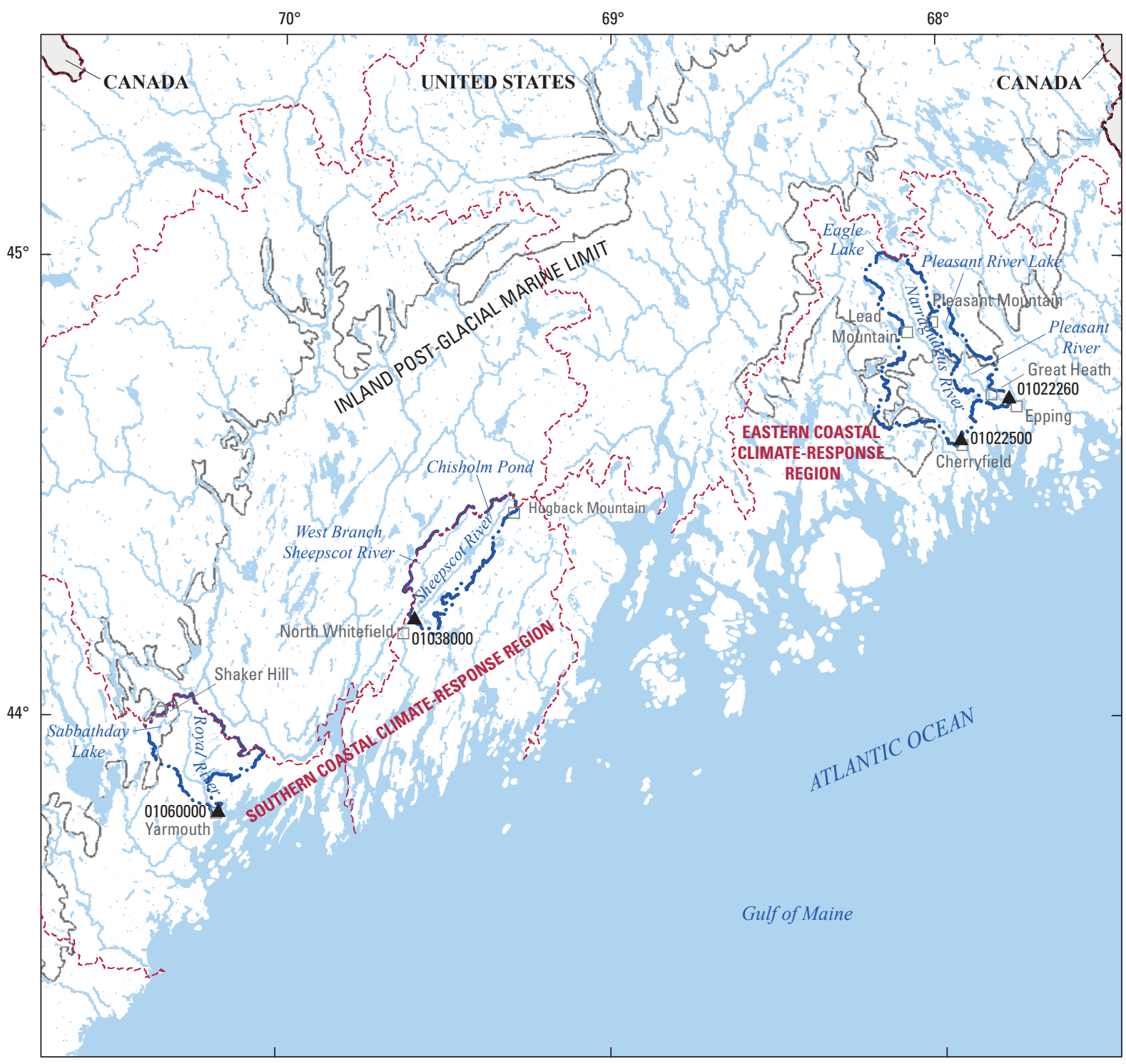

Base from U.S. Geological Survey and Maine Office of Geographic Information Systems digital files, North American Datum of 1983, Universal Transverse Mercator projection, Zone 19 Scale 1:1,320,000

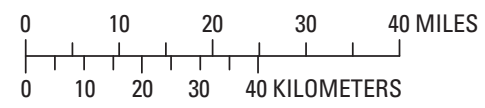

\section{EXPLANATION}

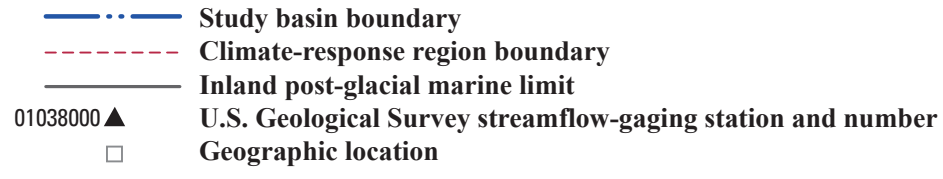

Figure 2. The study basins for the Pleasant, Narraguagus, Sheepscot, and Royal Rivers, Maine. 
5 and 7 imagery during the years 1999-2001 (U.S. Geological Survey, 2005) indicate that all of the four basins are rural and predominantly forested with deciduous, evergreen, and mixed-forest types or vegetated with scrub. Other prominent classifications of land-cover include forested wetlands and open water (lakes and ponds), pastures, and hay fields in the Sheepscot and the Royal River Basins, and blueberry barrens in the Narraguagus and the Pleasant River Basins. Otherwise, all of the study basins have sparsely scattered areas of cultivated land, light and heavy forest cuts, regenerating forest, and light residential development and road networks.

The largest change in land use that has occurred in these basins is the regeneration of forest in formerly clear-cut or agricultural lands. Since around 1880, when the maximum extent of the clearing of farmland and the harvesting of forests in Maine occurred, statewide forest cover has risen from about 70 to 90 percent. Irland (1998) estimated that as of 1995, about 90 percent of eastern coastal Maine (Washington and Hancock Counties, fig. 3) was forested, and that about 70 to 81 percent of southern coastal Maine (Waldo, Knox, Lincoln, Sagadahoc, Cumberland, and York Counties, fig. 3) was forested. About 22 percent of the forest land in Maine is composed of secondary forest on lands that were formerly farmed or pastured (Irland, 1998). Between 1880 and 1995, forest cover is estimated to have increased 18 percent in Washington County, 22 percent in Hancock County, 186 percent in Waldo County, 100 percent in Knox, Lincoln, Sagadahoc, and Cumberland Counties, and 150 percent in York County (Irland, 1998). Though a large amount of growth in forest cover has taken place since 1880, estimates of statewide forest cover have been stable for the last several decades (U.S. Department of Agriculture, 2005).

The study basins lie in a region of broad lowlands that the ocean inundated during deglaciation approximately 12,500 to 14,000 years ago as the margin of glacial ice retreated generally parallel to the present-day coastline (Randall, 2000; Hunter and Smith, 2001). The inland limit of marine inundation (fig. 2) has been determined on the basis of marine-limit altitude data and of the distribution of glaciomarine sediments (Thompson and Borns, 1985; Thompson and others, 1983). As a consequence of glacial retreat and marine inundation, most surficial geologic materials in the basins are compact glacial sediment (till), and the remainder of the materials are fine-grained glaciomarine deposits (typically silt, clay, and sand), marsh and bog deposits (typically peat, muck, clay, silt, and sand), and eskers (sand and gravel ridges deposited by glacial meltwater streams) (Thompson and Borns, 1985).

The Pleasant and Narraguagus River Basins were partially inundated during the glacial marine submergence; approximately the lower third of the gaged Narraguagus River Basin and the lower half of the gaged Pleasant River Basin were inundated. In the inundated regions of the basins, fine- and coarse-grained glaciomarine deposits (silt, clay, and sand) are characteristic of the main-channel corridors, and marsh and bog deposits characterize the Great Heath in the Pleasant River Basin. The remaining portions of the basins are predominantly composed of till interspersed with ice-contact glaciofluvial deposits of sand and gravel. The Sheepscot River Basin was entirely inundated during the glacial marine submergence. Fine- and coarse-grained glaciomarine deposits are characteristic of the West Branch Sheepscot corridor, with the remainder of the basin composed of till and a few eskers. The Royal River Basin was almost entirely inundated during the late glacial marine submergence. Fine- and coarse-grained glaciomarine deposits (silt, clay, and sand) are characteristic of the main-channel corridors, with the remainder of the basin largely composed of till (Thompson and Borns, 1985).

\section{Climate}

The climate of coastal Maine is temperate, with mild summers and cold winters. The mean annual air temperature in eastern coastal Maine, from 1971 to 2000 , ranged from $42.8^{\circ} \mathrm{F}$ (at Jonesboro, altitude $185 \mathrm{ft}$ ) to $45.2^{\circ} \mathrm{F}$ (at Belfast, altitude $30 \mathrm{ft}$ ) with mean monthly air temperatures ranging from $18.2^{\circ} \mathrm{F}$ in January (at Jonesboro) to $68.2^{\circ} \mathrm{F}$ in July (at Belfast) (National Oceanic and Atmospheric Administration, 2002) (fig. 3). The mean annual air temperature in southern coastal Maine during the same 30 -year period ranged from $44.1^{\circ} \mathrm{F}$ (at West Buxton, altitude $150 \mathrm{ft}$ ) to $45.7^{\circ} \mathrm{F}$ (at Portland International Airport, altitude $45 \mathrm{ft}$ ) with mean monthly air temperatures ranging from $18.3^{\circ} \mathrm{F}$ in January (at West Buxton) to $68.7^{\circ} \mathrm{F}$ in July (at Portland International Airport) (National Oceanic and Atmospheric Administration, 2002).

Precipitation is fairly evenly distributed during the year throughout coastal Maine. Annual mean precipitation in eastern coastal Maine, from 1971 to 2000, ranged from 47.6 in. (at Belfast) to 51.3 in. (at Jonesboro); Annual mean precipitation in southern coastal Maine ranged from 44.7 in. (at Port Clyde, altitude $30 \mathrm{ft}$ ) to 48.0 in. (at Brunswick Naval Air Station, altitude $70 \mathrm{ft}$ ) (National Oceanic and Atmospheric Administration, 2002) (fig. 3). Mean annual evapotranspiration (loss of water to the atmosphere by evaporation from the soil and transpiration from plants) from 1951 through 1980 ranged from about 18 in. in eastern coastal Maine to 19 in. in southern coastal Maine (Randall, 1996).

\section{Streamflow}

Flow in rivers in coastal Maine is maintained by a combination of groundwater inflow and surface runoff. The proportions are not consistent through time and depend on climate, seasonal weather conditions, surficial geology, and land cover. Median monthly streamflows in the four study basins, recorded at USGS streamgages 01022260, 01022500 , 01038000 , and 01060000 show a seasonal variation that is common in Maine (fig. 4). The largest streamflows in coastal Maine typically occur in the spring (March, April, and May), when rain falls on dense (ripe) snowpack or on saturated soils. Streamflow then recedes as snowmelt ends and evapotranspiration increases. The recession of streamflow typically persists into late summer and early autumn (August and September) because of high evapotranspiration. Streamflow in 


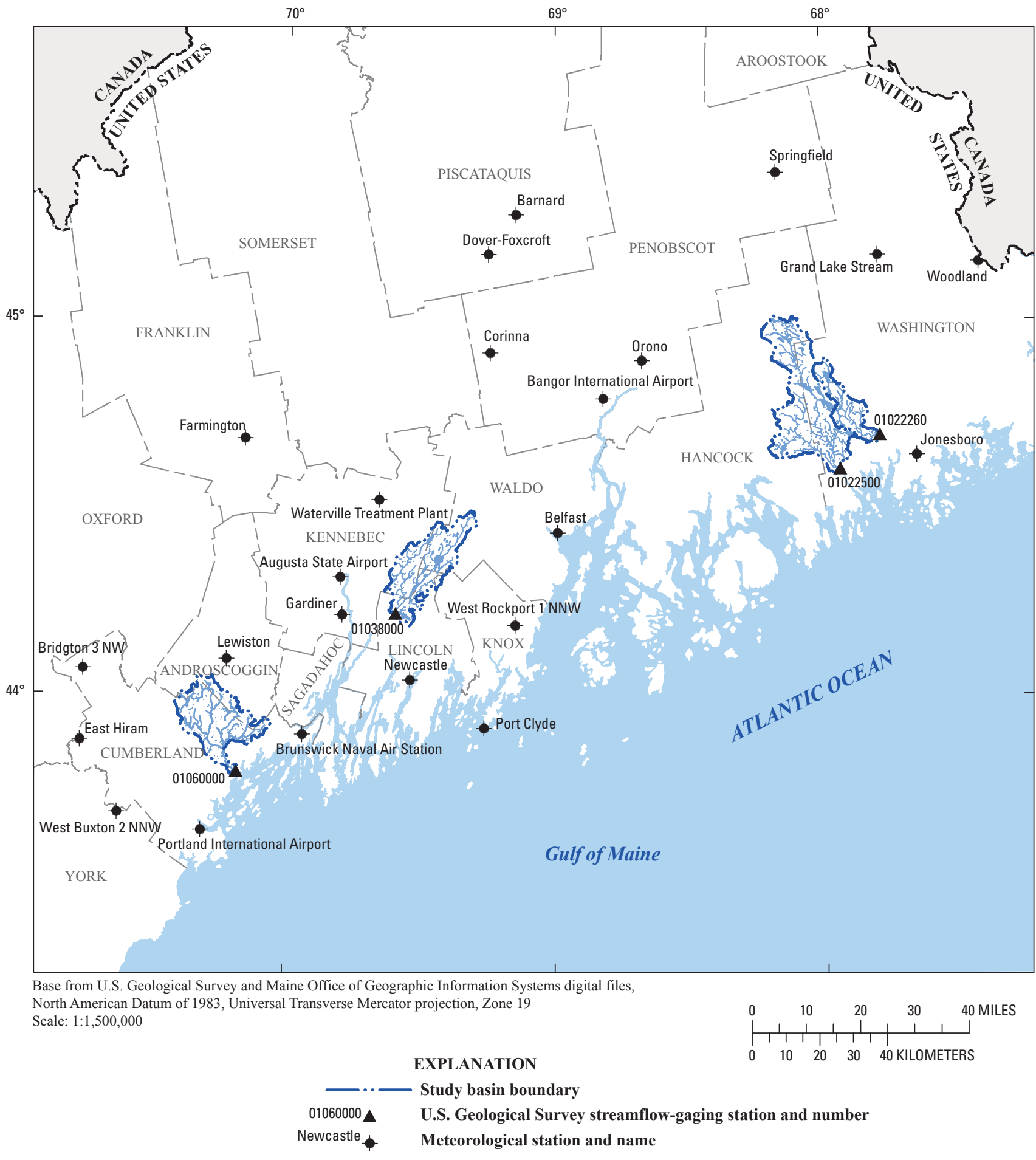

Figure 3. Network of Maine meteorological stations supplying precipitation and air temperature data used in this investigation. 


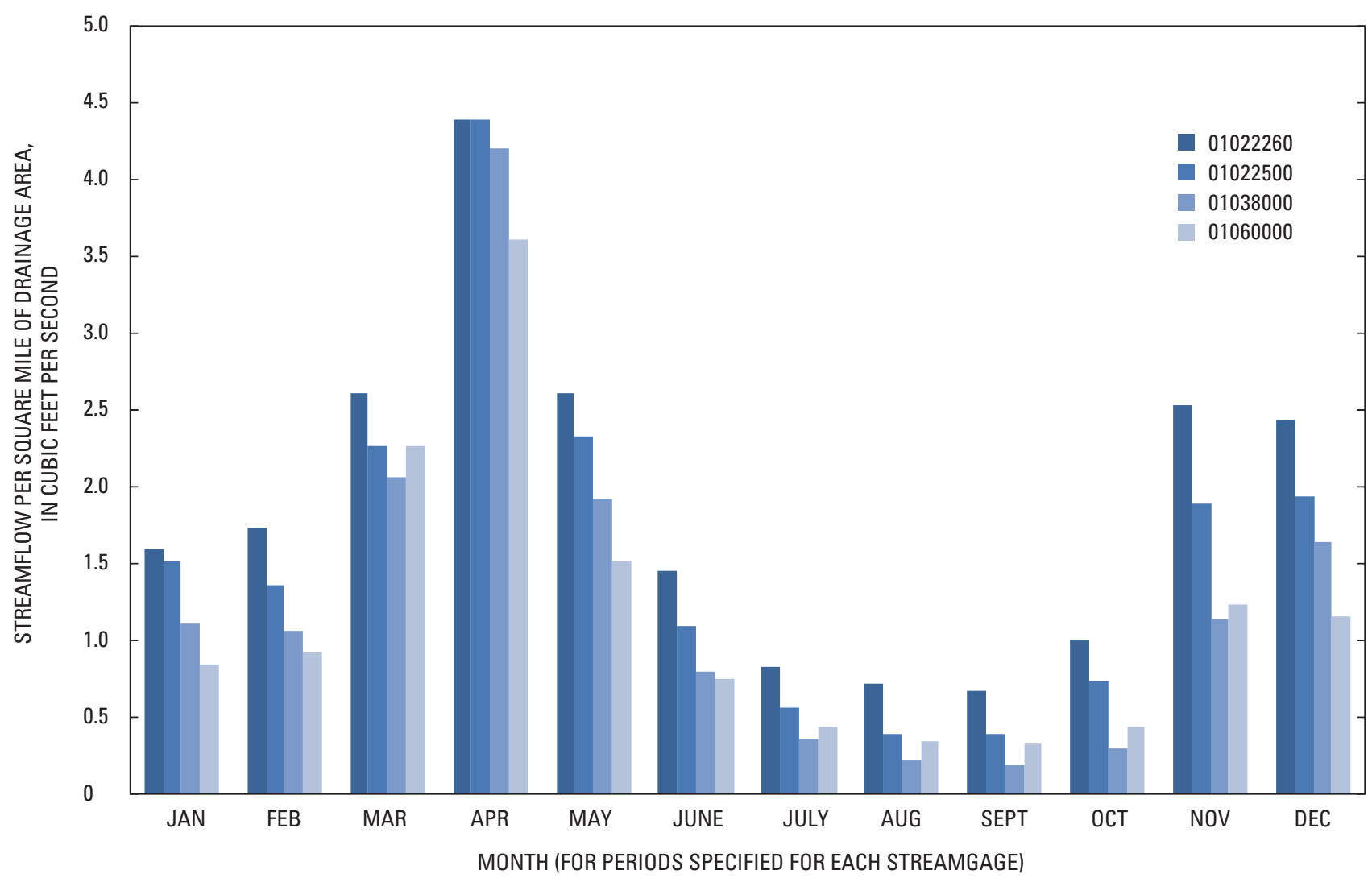

Figure 4. Median monthly streamflows measured at U.S. Geological Survey streamgages on the Pleasant (01022260), Narraguagus (01022500), Sheepscot (01038000), and Royal Rivers (01060000), Maine. Statistics for Pleasant River were computed on the basis of daily mean streamflow data collected during calendar years 1980-91 and 2001-08; for the Narraguagus River on the basis of data during 1948-2008; for the Sheepscot River on the basis of data during 1938-2008; and for the Royal River on the basis of data during 1949-2004.

late summer is often dominated by groundwater discharge or storage release from lakes and wetlands and is frequently augmented by runoff from rainfall events. As evapotranspiration decreases in the autumn (October and November), streamflow increases. Repeated rainfall events and the occasional contribution of precipitation related to a tropical system can result in high streamflow during the autumn. Low streamflow can occur during the winter (December, January, and February) if precipitation and surface water are frozen for extended periods of time.

\section{Methods of Study}

The following sections document the data used for analyses, limitations of those data, and the analyses performed, including a description of the watershed modeling application used and its input requirements.

\section{Data Used}

Streamflow data were collected by the USGS using techniques described by Rantz and others (1982). Streamflow data have been continuously collected at the streamgage on the Pleasant River (01022260) since 1980, at the Narraguagus River streamgage (01022500) since 1948, at the Sheepscot River streamgage (01038000) since 1938, and at the Royal River streamgage (01060000) since 1949 (figs. 2 and 4; table 1). Continuous streamflow data used in this study were retrieved from the National Water Information System (NWIS, http://waterdata.usgs.gov/nwis/, accessed April 2010). Since 1980, data are common to all four study basins and were therefore used for this study for calibrating and evaluating the watershed models. The same time period 1980-2007 also was chosen to be congruent with the National Climate Change Modeling Project (Markstrom and Hay, 2009) in order to more effectively compare between projects, and also in case these models are to be included in future national modeling efforts. 
Table 1. U.S. Geological Survey streamgages used in this study, coastal Maine.

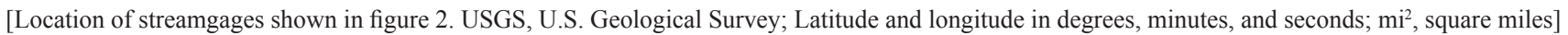

\begin{tabular}{clccccc}
\hline Number & \multicolumn{1}{c}{ USGS streamgage } & \multicolumn{1}{c}{$\begin{array}{c}\text { Latitude } \\
\text { (north) }\end{array}$} & $\begin{array}{c}\text { Longitude } \\
\text { (west) }\end{array}$ & $\begin{array}{c}\text { Altitude } \\
\text { (feet) }\end{array}$ & $\begin{array}{c}\text { Drainage area } \\
\text { measured at gage } \\
\text { (mi²) }\end{array}$ & $\begin{array}{c}\text { Period of record } \\
\text { used }\end{array}$ \\
\hline 01022260 & Pleasant River near Epping & $44^{\circ} 41^{\prime} 52^{\prime \prime}$ & $67^{\circ} 47^{\prime} 14^{\prime \prime}$ & 127 & 60.6 & $1980-91,2000-07$ \\
01022500 & Narraguagus River at Cherryfield & $44^{\circ} 36^{\prime} 29^{\prime \prime}$ & $67^{\circ} 56^{\prime} 7^{\prime \prime}$ & 44 & 227 & $1980-2007$ \\
01038000 & Sheepscot River at North Whitefield & $44^{\circ} 13^{\prime} 22^{\prime \prime}$ & $69^{\circ} 35^{\prime} 38^{\prime \prime}$ & 101 & 145 & $1980-2007$ \\
01060000 & Royal River at Yarmouth & $43^{\circ} 47^{\prime} 57^{\prime \prime}$ & $70^{\circ} 10^{\prime} 42^{\prime \prime}$ & 10 & 141 & $1980-2004$ \\
\hline
\end{tabular}

Daily precipitation and minimum and maximum air temperature data were used from 23 meteorological stations (fig. 3; table 2) in the National Oceanic and Atmospheric Administration's National Weather Service Cooperative Observer Program (National Oceanic and Atmospheric Administration Cooperative Observer Program, U.S. National Weather Service database accessed April 2010, at http://www. nws.noaa.gov/om/coop/). Streamflow data from the NWIS network and meteorological data from the NOAA COOP network were both retrieved using the USGS Downsizer computer application (Ward-Garrison and others, 2009) written in the Java programming language (http://java.sun. com, accessed April 2010), and designed for selecting, downloading, and verifying station-based time-series data for modeling environmental resources.

A 1:24,000-scale USGS digital elevation model (DEM) of the study basins was used to describe physical attributes of the basins. This $32.8-\mathrm{ft}(10 \mathrm{~m}) \mathrm{DEM}$ is a geographic information system (GIS) dataset containing a spatial grid of data, $32.8 \mathrm{ft}$ on center, with altitude reported at each grid point. DEM data were downloaded from the USGS National Map Seamless Server (U.S. Geological Survey, 2008).

Additional physical attributes of the basins were described using data on soil, land cover, and forest speciation and density. The U.S. General Soil Map (STATSGO) (U.S. Department of Agriculture, 1994) delineates general soil units and was derived by the National Cooperative Soil Survey using 1:250,000-scale topographic quadrangles. This investigation used STATSGO to broadly describe surficial soils and soil profile properties in the basins. Quality assurance and refinements of soil characteristics were made using a surficial geologic map of Maine (Thompson and Borns, 1985).

Types of land cover were characterized using version 2.0 of the North American Land Cover Characteristics Data Base (NALCC); data which the USGS derived in cooperation with the University of Nebraska and the European Commission's Joint Research Centre from satellite imagery collected during 1992-93 (Loveland and others, 1991). These data were used to broadly classify land-cover types in the basins. Quality assurance and refinement of land-cover types were achieved using a digital land-cover dataset for the State of Maine derived from satellite imagery from the years 1999-2001 and panchromatic imagery from 2004 (Maine Office of Geographic Information Systems (MEGIS), Maine LandCover Dataset (MELCD), accessed June 21, 2006, at http://megis.maine.gov/catalog/).

The U.S. Forest Type Groups and U.S. Forest Density maps were used to broadly characterize dominant forest speciation and vegetation density in the basins. Both datasets are published by the U.S. Forest Service (Zhu and Evans, 1994; Zhu, 1994). Solar radiation data were spatially interpolated using regression analysis of a nationwide climate network of Natural Resources Conservation Service snowpack telemetry stations and NWS climate stations (Hay and others, 2006). Mean monthly potential evapotranspiration (PET) data were interpolated from maps produced by the NWS derived from the free water evaporation atlas of Farnsworth and others (1982).

\section{Watershed Model}

In general, watershed models simulate the generation of runoff from a basin when rain reaches the surface of the ground and meltwater forms on the surface of the ground. Typical input to a watershed model may include precipitation, air temperature, solar radiation, wind, and parameters describing the physical characteristics of the basin, including slope, aspect, elevation, and soil types. The models use various algorithms and methods of approximation to describe the physical processes that affect the movement of water over and through the soil. Runoff processes simulated by a watershed model may include overland flow, shallow subsurface flow, and groundwater flow. Typical output from a watershed model is a data time-series of the rate of runoff for a point of interest (on a hillside or in a channel) that represents the integrated hydrologic response of the upstream drainage area to precipitation input on the basis of a basin's climatic, hydrologic, and physical characteristics.

The USGS Precipitation-Runoff Modeling System (PRMS) (Leavesley and others, 2005; Leavesley and others, 1983) was used in this investigation to simulate daily 
Table 2. National Oceanic and Atmospheric Administration's National Weather Service Cooperative Observer Program meteorological stations used in this investigation in the vicinity of the coastal study basins, Maine.

[Latitude and longitude in degrees, minutes, and seconds; NW, northwest; NNW, north, northwest]

\begin{tabular}{|c|c|c|c|c|c|}
\hline \multicolumn{2}{|r|}{ Meteorological station } & \multirow{2}{*}{$\begin{array}{l}\text { Latitude } \\
\text { (north) }\end{array}$} & \multirow{2}{*}{$\begin{array}{l}\text { Longitude } \\
\text { (west) }\end{array}$} & \multirow{2}{*}{$\begin{array}{c}\text { Altitude } \\
\text { (feet) }\end{array}$} & \multirow{2}{*}{ Period of record used } \\
\hline Number & Name & & & & \\
\hline 170275 & Augusta State Airport & $44^{\circ} 19^{\prime}$ & $69^{\circ} 48^{\prime}$ & 350 & 1980-2007 \\
\hline 170355 & Bangor International Airport & $44^{\circ} 48^{\prime}$ & $68^{\circ} 49^{\prime}$ & 148 & 1980-95, 1999-2007 \\
\hline 170398 & Barnard & $45^{\circ} 17^{\prime}$ & $69^{\circ} 9^{\prime}$ & 545 & 1990-2007 \\
\hline 170480 & Belfast & $44^{\circ} 26^{\prime}$ & $68^{\circ} 59^{\prime}$ & 30 & 1980-2007 \\
\hline 170844 & Bridgton $3 \mathrm{NW}$ & $44^{\circ} 4^{\prime}$ & $70^{\circ} 45^{\prime}$ & 560 & $1980-2007$ \\
\hline 170934 & Brunswick Naval Air Station & $43^{\circ} 54^{\prime}$ & $69^{\circ} 56^{\prime}$ & 70 & 1980-2007 \\
\hline 171628 & Corinna & $44^{\circ} 55^{\prime}$ & $69^{\circ} 15^{\prime}$ & 297 & 1980-2007 \\
\hline 171975 & Dover-Foxcroft & $45^{\circ} 11^{\prime}$ & $69^{\circ} 15^{\prime}$ & 460 & 1980-2007 \\
\hline 172238 & East Hiram & $43^{\circ} 53^{\prime}$ & $70^{\circ} 45^{\prime}$ & 528 & 1980-2007 \\
\hline 172765 & Farmington & $44^{\circ} 41^{\prime}$ & $70^{\circ} 9^{\prime}$ & 420 & 1980-2007 \\
\hline 173046 & Gardiner & $44^{\circ} 13^{\prime}$ & $69^{\circ} 47^{\prime}$ & 140 & 1980-2007 \\
\hline 173261 & Grand Lake Stream & $45^{\circ} 11^{\prime}$ & $67^{\circ} 47^{\prime}$ & 290 & 1980-2007 \\
\hline 174183 & Jonesboro & $44^{\circ} 39^{\prime}$ & $67^{\circ} 39^{\prime}$ & 185 & 1980-2007 \\
\hline 174566 & Lewiston & $44^{\circ} 6^{\prime}$ & $70^{\circ} 13^{\prime}$ & 180 & 1980-2007 \\
\hline 175675 & Newcastle & $44^{\circ} 3^{\prime}$ & $69^{\circ} 32^{\prime}$ & 190 & $1980-2007$ \\
\hline 176430 & Orono & $44^{\circ} 54^{\prime}$ & $68^{\circ} 40^{\prime}$ & 115 & 1980-2001, 2003-05 \\
\hline 176881 & Port Clyde & $43^{\circ} 55^{\prime}$ & $69^{\circ} 16^{\prime}$ & 30 & 1989-2007 \\
\hline 176905 & Portland International Airport & $43^{\circ} 39^{\prime}$ & $70^{\circ} 18^{\prime}$ & 45 & 1980-2007 \\
\hline 178353 & Springfield & $45^{\circ} 24^{\prime}$ & $68^{\circ} 10^{\prime}$ & 440 & 1980-1998 \\
\hline 179151 & Waterville Treatment Plant & $44^{\circ} 32^{\prime}$ & $69^{\circ} 39^{\prime}$ & 73 & 1980-2007 \\
\hline 179314 & West Buxton 2 NNW & $43^{\circ} 41^{\prime}$ & $70^{\circ} 37^{\prime}$ & 150 & 1980-2007 \\
\hline 179593 & West Rockport 1 NNW & $44^{\circ} 12^{\prime}$ & $69^{\circ} 9^{\prime}$ & 380 & 1980-2007 \\
\hline 179891 & Woodland & $45^{\circ} 9^{\prime}$ & $67^{\circ} 24^{\prime}$ & 140 & 1980-2007 \\
\hline
\end{tabular}

streamflows for the study basins. PRMS is well-suited for modeling runoff from rural basins and has been applied to many basins in the United States including the Dennys River Basin (Dudley, 2008), Willamette River Basin, Oregon (Laenen and Risley, 1997), Methow River Basin, Washington (Ely and Risley, 2001; Ely 2003), Yakima River Basin, Washington (Mastin and Vaccaro, 2002), Feather River Basin, California (Koczot and others, 2004), Yampa River Basin, Colorado (Parker and Norris, 1989), Ah-Shi-Sle-Pah Wash Basin, New Mexico (Hejl, 1989), Lake Tahoe and Truckee River Basins, California and Nevada (Jeton, 1999a, b), Williams Draw and Bush Draw Basins, Colorado (Kuhn, 1989), Tug Fork River Basin of Kentucky, Virginia, and West Virginia (Scott, 1984), 10 basins in Vermont (Olson, 2002), and Bald Mountain and Bishop Mountain Brook Basins, Maine (Fontaine, 1987).

PRMS is a deterministic, distributed-parameter modeling system. The model is deterministic in that it computationally incorporates multiple components of the hydrologic cycle as understood through known physical laws or empirical relations in hydrologic science. The modeled hydrologic relations are typically governed by quantifiable physical characteristics of the basin. Parameters describing these characteristics are assigned in a distributed fashion, representing the spatial variation (heterogeneity) in basin characteristics. In this manner, the deterministic, distributed-parameter model is designed to simulate the hydrologic system as explicitly as possible.

Parameters describing the physical characteristics of a basin are distributed among subbasins that are referred to as Hydrologic Response Units (HRUs), or Model Response Units (MRUs) (this report refers to the units as MRUs). The size of an MRU is determined on the basis of spatial variation of physical characteristics across the basin; MRUs are intended to encompass regions with approximately homogeneous characteristics of a basin such as slope, aspect, soil type, and 
vegetation type, among others. A lake or wetland is commonly represented by a single MRU because of its homogeneous characteristics, for example. Other regions within the basin may be represented by one, two, or more MRUs, depending on the degree of variability in topography, soils, and other basin characteristics.

The following paragraphs from Leavesley and others (1983, p. 7-9) provide a good summary of the operational design of PRMS (fig. 5).

"System inputs are precipitation, air temperature, and solar radiation. Precipitation in the form of rain, snow, or a mixture of both is reduced by interception [precipitation intercepted by vegetation] and becomes net precipitation delivered to the watershed surface. The energy inputs of temperature and solar radiation drive the processes of evaporation [vaporization of water at the water's surface], transpiration [evaporation of water through vegetation], sublimation [vaporization of water from the solid snow/ice phase], and snowmelt. The watershed system is conceptualized as a series of reservoirs whose outputs combine to produce the total system response.

The impervious-zone reservoir represents an area with no infiltration capacity. The reservoir has a maximum retention storage capacity which must be satisfied before surface runoff will occur. Retention storage is depleted by evaporation when the area is snow free.

The soil-zone reservoir represents that part of the soil mantle that can lose water through the processes of evaporation and transpiration. Average rooting depth of the predominant vegetation covering the soil surface defines the depth of this zone. Water storage in the soil zone is increased by infiltration of rainfall and snowmelt and depleted by evapotranspiration. Maximum retention storage occurs at field capacity; minimum storage (assumed to be zero) occurs at wilting point. The soil zone is treated as a two-layered system. The upper layer is termed the recharge zone and is user-defined as to depth and water-storage characteristics. Losses from the recharge zone are assumed to occur from evaporation and transpiration; losses from the lower zone occur only through transpiration.

The computation of infiltration into the soil zone is dependent on whether the input source is rain or snowmelt. All snowmelt is assumed to infiltrate until field capacity is reached. At field capacity, any additional snowmelt is apportioned between infiltration and surface runoff. At field capacity, the soil zone is assumed to have a maximum daily snowmelt infiltration capacity. All snowmelt in excess of this capacity contributes to surface runoff. Infiltration in excess of field capacity first is used to satisfy recharge to the groundwater reservoir [deep reservoir], having a maximum daily limit. Excess infiltration, above this limit, becomes recharge to the subsurface reservoir [shallow reservoir]. Water available for infiltration as the result of a rain-on-snow event is treated as snowmelt if the snowpack is not depleted and as rainfall if the snowpack is depleted.

For rainfall with no snowcover, the volume infiltrating the soil zone is computed as a function of soil characteristics, antecedent soil-moisture conditions, and storm size. For daily-flow computations, the volume of rain that becomes surface runoff is computed using a contributing-area concept [defining areas in the basin that contribute to runoff]. Daily infiltration is computed as net precipitation less surface runoff.

The subsurface reservoir performs the routing of soil-water excess that percolates to shallow groundwater zones near stream channels or that moves downslope from point of infiltration to some point of discharge above the water table. Subsurface flow is considered to be water in the saturated-unsaturated and groundwater zones that is available for relatively rapid movement to a channel system. The subsurface reservoir can be defined either as linear or nonlinear.

Recharge to the groundwater reservoir can occur from the soil zone and the subsurface reservoir. Soil zone recharge has a daily upper limit and occurs only when field capacity is exceeded in the soil zone. Subsurface reservoir recharge is computed daily as a function of a recharge rate coefficient and the volume of water stored in the subsurface reservoir. The groundwater reservoir is a linear reservoir and is the source of all baseflow. Streamflow is the sum of direct surface runoff, subsurface flow, and baseflow from each [MRU]."

The Modular Modeling System (MMS), developed by Leavesley, Markstrom, and others (1996; Leavesley, Restrepo, and others, 1996), is a software application that provides a framework for developing and integrating algorithms for physical-process models (Leavesley and others, 2005). Process-specific algorithms for PRMS are stored in MMS in a module library from which the algorithms can be selected to construct models that simulate a variety of water, energy, and biogeochemical processes. This modular approach to modeling enables users to construct custom models using existing modules or to develop custom modules for specific applications. The 15 PRMS-specific modules included in the watershed models used in this investigation are described in table 3. 


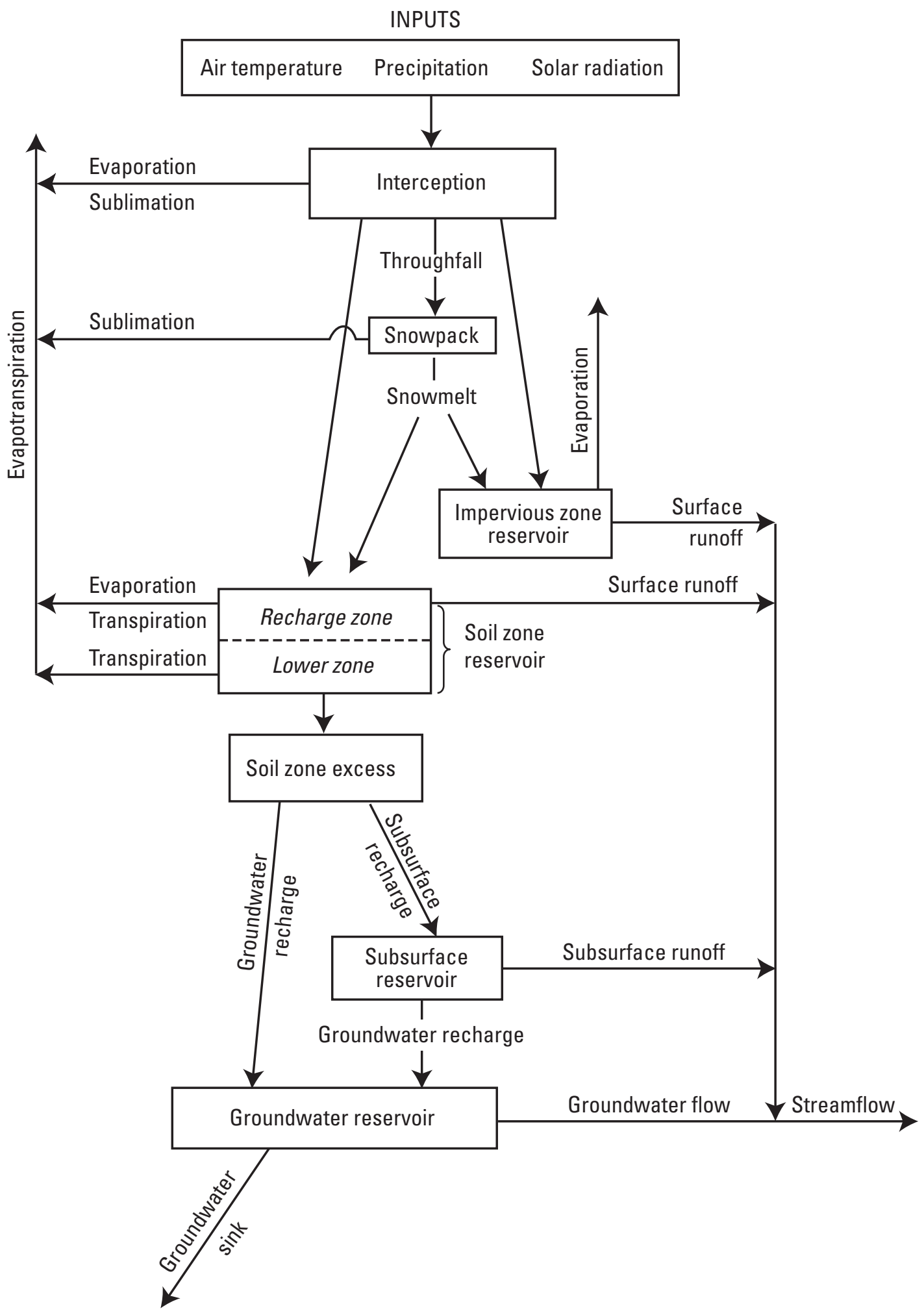

Figure 5. Schematic diagram of the operational design of the Precipitation Runoff Modeling System (PRMS). Modified from figure 2 in Leavesley and others (1983, p. 8). 
Table 3. Modular Modeling System (MMS) Modules used in the Precipitation-Runoff Modeling System for this investigation.

[MRU, model response unit; (U.S. Geological Survey, 2009)]

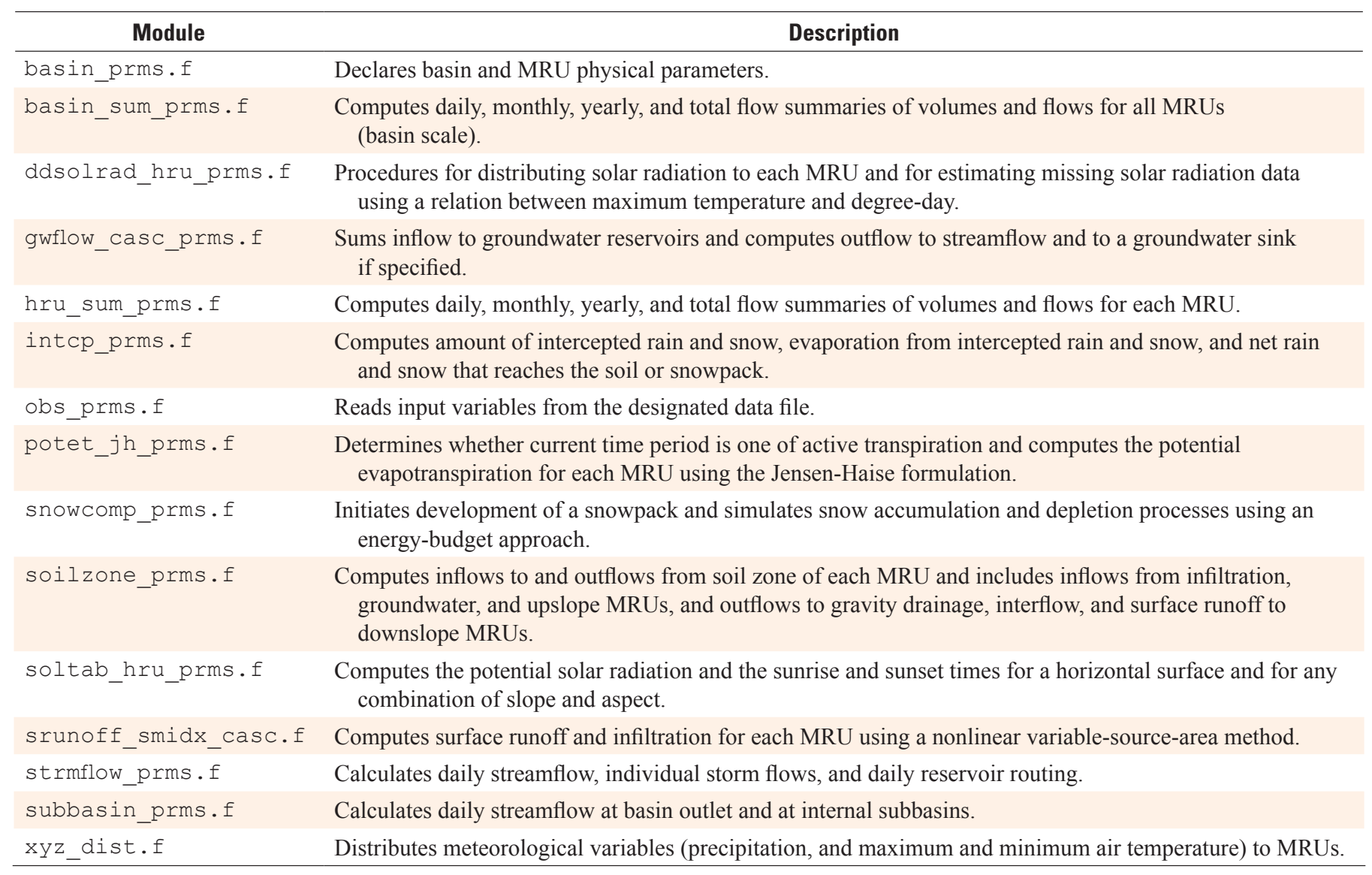

\section{Characterization of the Basins and Initial Parameterization}

The GIS Weasel (Viger and Leavesley, 2007), a geographic information system (GIS) interface, was used to subdivide the basin into MRUs and to calculate parameters for each of the watershed models. The GIS Weasel provides a suite of tools to help prepare spatial information, lumped or distributed, for input to watershed or other environmental models. Using this set of tools provides objective and reproducible methods for generating input parameters for a model. In this investigation, the GIS Weasel was used to delineate the basins, subdivide the basins into MRUs, and characterize the basins' physical features into the requisite sets of parameters for input to PRMS.

The GIS Weasel requires as input a hydrocorrected DEM of the basin to be modeled. The ArcHydro data model and tools (Djokic, 2008) were used to pre-process and hydrocorrect the raw DEM (for example, topographical sinks need to be filled so that all water is routed downstream). Using the DEM, the GIS Weasel generates a flow-direction surface, which in turn, is used to derive a flow-accumulation surface. Each point on the flow-accumulation surface designates the upstream drainage area. A drainage network is extracted from this surface by finding all points at which the flow accumulation is equal to or greater than a user-specified threshold (Viger and Leavesley, 2007). In this investigation, the threshold was calculated as a function of the size of the basin. A threshold of $0.096 \mathrm{mi}^{2}$ was used for the smallest subbasin (an interior drainage basin that contributes to the overall drainage basin) (Pleasant River), up to a threshold of $0.38 \mathrm{mi}^{2}$ for the largest subbasin (Narraguagus River). These thresholds generated a stream network of suitable density for each basin. Using the flow-direction surface, the GIS Weasel delineated basin boundaries on the basis of user-specified pour points, or basin outlets. The pour point for each basin was identified as the location of the USGS streamgage (01022260, 01022500 , 01038000 , or 01060000 ) on each of the four rivers. 
Next, the GIS Weasel was used to derive MRUs for each basin. Initial MRUs were defined by determining the contributing area associated with the stream segment for each subbasin in the drainage network and splitting these areas with the same drainage network into "left-bank" and "right-bank" units. Additional MRUs were formed on the basis of specific geologic or hydrologic features including significant sand and gravel deposits, wetlands (such as the Great Heath), and bodies of water for which specific model parameters would later be defined to describe the features' unique hydrologic properties. The process resulted in the delineation of 99 MRUs for the Pleasant River Basin, 198 MRUs for the Narraguagus River Basin, 138 MRUs for the Sheepscot River Basin, and 140 MRUs for the Royal River Basin (fig. 6; table 4).

The GIS Weasel was used to derive parameter values for the physical geographic features of the study basins (parameterization) using the U.S. General Soil Map, North American Land Cover Characteristics Data Base, U.S. Forest Type Groups, and U.S. Forest Density maps, and the DEM and its aforementioned derivative surfaces. Parameters derived for each MRU included area, elevation, slope, aspect, vegetation type and density, capacities for intercepting precipitation, and soil types (table 5). During parameterization, the GIS Weasel also determined MRU-specific indices describing connectivity of MRUs with the drainage network and with surface-water and groundwater reservoirs. The MRU responses were grouped by subbasins, enabling output from the models to provide estimates of streamflow at any subbasin within each basin.

\section{Meteorological Data Input}

Daily meteorological data (precipitation, and minimum and maximum air temperature) were provided as input to each watershed model. A multiple linear regression (MLR) method was used to spatially assign daily meteorological data, measured at NOAA cooperative observer program (COOP) stations proximal to each study basin, among the MRUs for each basin model. Explanatory variables for each MLR equation are longitude $(x)$, latitude $(y)$, and elevation $(z)$ (Hay and others, 2000).

For each meteorological variable $(M V)$ and basin, an MLR equation was derived for each month to explain the spatial variability of precipitation and of air temperature across the study basins. Each monthly MLR equation thereby provided the means to compute the daily $M V$ at each MRU in a watershed model as a function of each MRU centroid location in space $(x, y$, and $z)$. The derivation of each MLR required the computation of coefficients $b_{0}, b_{1}, b_{2}$, and $b_{3}$ (equation 1 ) for each $M V$ for each month, on the basis of meteorological station data in or near each study basin:

$$
M V=b_{0}+b_{1} x+b_{2} y+b_{3} z
$$

where

$$
\begin{array}{cc}
M V \quad \text { is the meteorological variable: daily } \\
\text { precipitation, in inches, or daily minimum } \\
\text { temperature, in degrees Fahrenheit, or } \\
\text { daily maximum temperature, in degrees } \\
\text { Fahrenheit; } \\
b_{1}, b_{2}, b_{3} \quad \text { is the regression equation intercept; } \\
x \quad \text { is the geographic } x \text { coordinate for the } \\
\text { meteorological station, in feet; } \\
y \quad \text { is the geographic } y \text { coordinate for the } \\
\text { meteorological station, in feet; and } \\
\text { is the elevation for the meteorological station, } \\
\text { in feet. }
\end{array}
$$

Proximal meteorological stations were iteratively included and excluded in the MLR derivation procedure until a satisfactory regression for each $M V$ was obtained (table 6). Satisfactory regression equations included multiple meteorological stations (table 6) and were evaluated on the basis of linearity, homogeneity of variance, and normality of the distribution of residuals (Helsel and Hirsch, 1992). The PRMS module xyz_dist.f (table 3) applied the derived MLRs to distribute the meteorological variables to MRUs when the models were run.

Table 4. Model Response Units (MRUs) per study basin, ranges of size, and mean size, Maine.

[USGS, U.S. Geological Survey; $\mathrm{mi}^{2}$, square miles]

\begin{tabular}{clcccc}
\hline & USGS streamgages & \multirow{2}{*}{ Name } & Number of MRUs & \multicolumn{3}{c}{ MRU size $\left(\mathbf{m i}^{2}\right)$} \\
\cline { 5 - 6 } Number & \multicolumn{1}{c}{} & & Minimum & Maximum & Mean \\
\hline 01022260 & Pleasant River near Epping & 198 & 0.1 & 2.5 & 0.6 \\
01022500 & Narraguagus River at Cherryfield & 138 & 0.4 & 5.2 & 1.1 \\
01038000 & Sheepscot River at North Whitefield & 140 & 0.1 & 3.5 & 1.0 \\
01060000 & Royal River at Yarmouth & & 0.2 & 4.2 & 1.0 \\
\hline
\end{tabular}


$\boldsymbol{A}$
$A$
$68^{\circ} 0$
$67^{\circ} 55^{\prime}$
$67^{\circ} 50^{\prime}$
$67^{\circ}$

$44^{\circ} 55^{\prime}$
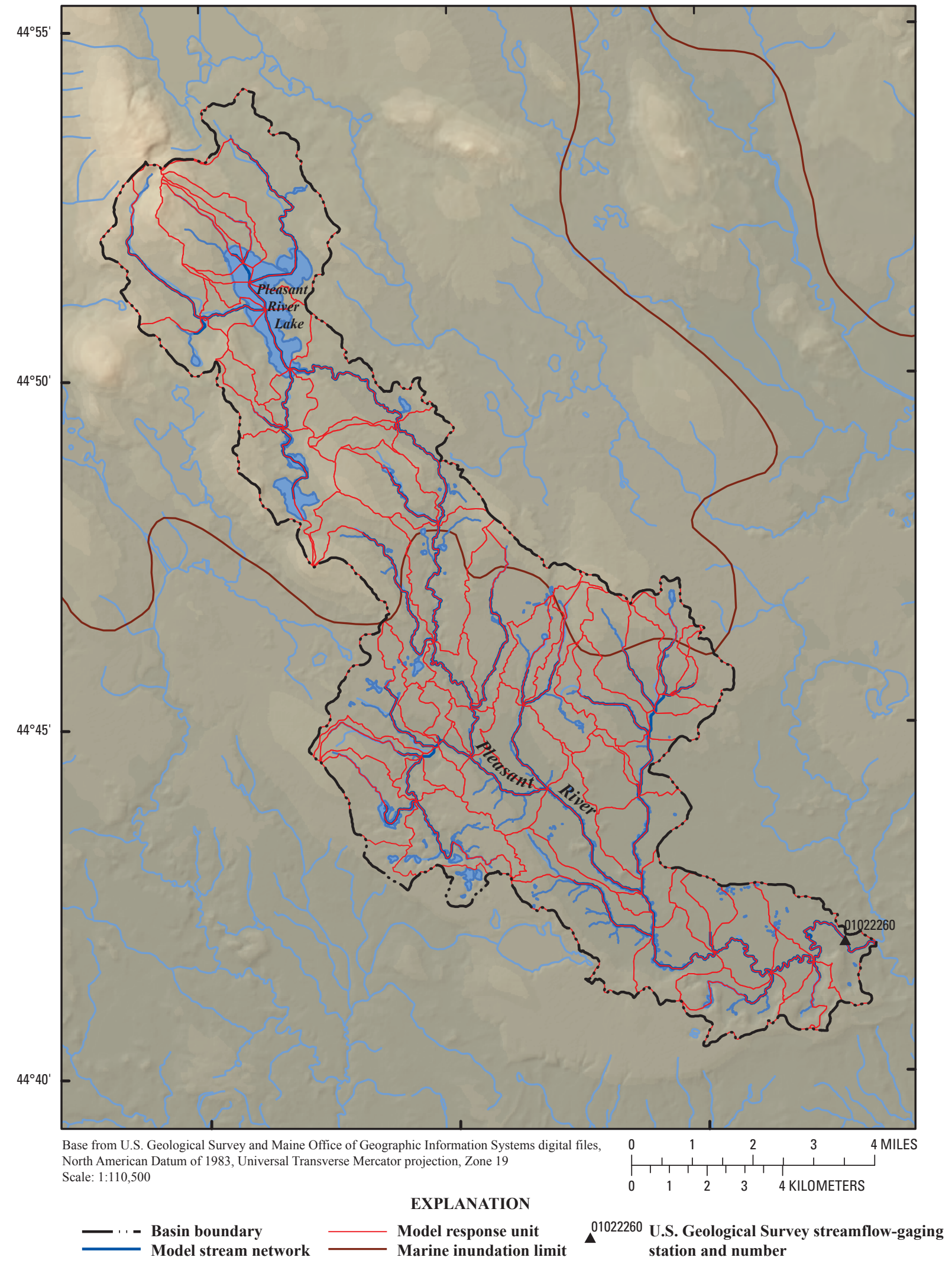

Figure 6. Model Response Units and drainage networks for the watershed models of the (A) Pleasant, (B) Narraguagus, (C) Sheepscot, and (D) Royal Rivers. 
B

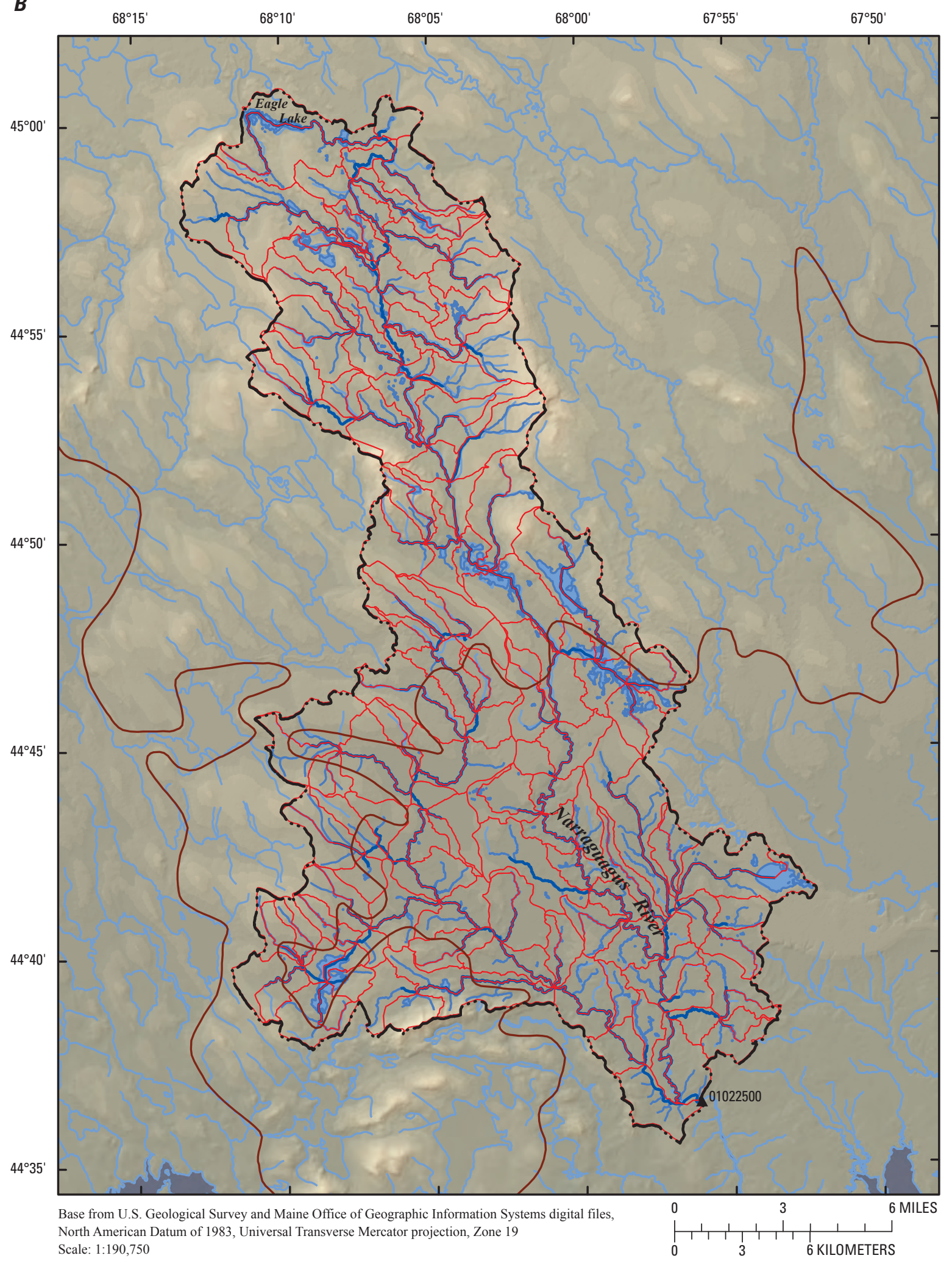

EXPLANATION

\begin{tabular}{l} 
- Basin boundary \\
\hline
\end{tabular}

Model response unit

Marine inundation limit

$\Lambda^{01022500}$ U.S. Geological Survey streamflow-gaging station and number

Figure 6. Model Response Units and drainage networks for the watershed models of the (A) Pleasant, $(B)$ Narraguagus, (C) Sheepscot, and (D) Royal Rivers.-Continued 
C

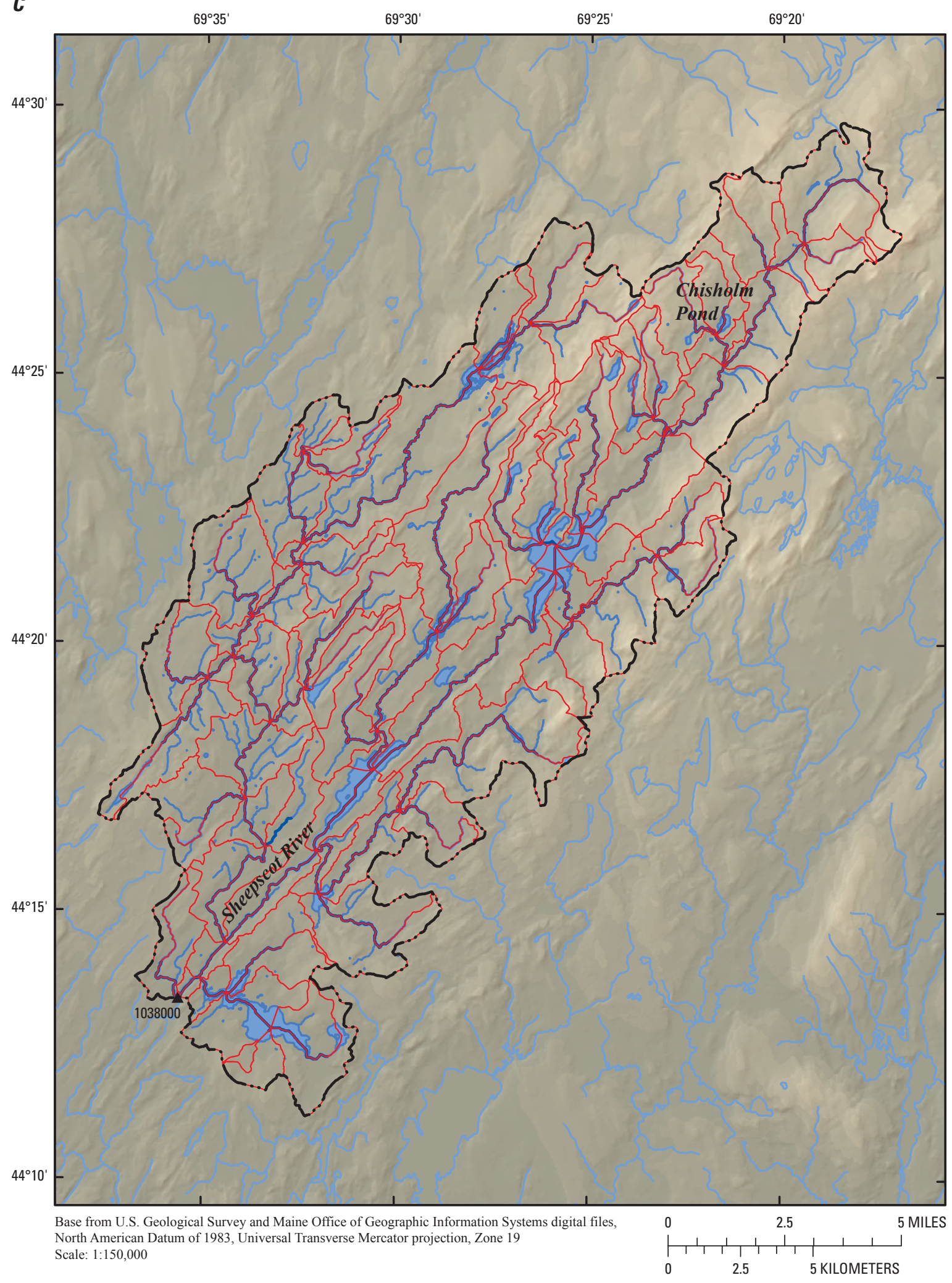

EXPLANATION

$-\cdots$ - Basin boundary
Model stream network

Model response unit

01038000 U.S. Geological Survey streamflow-gaging station and number

Figure 6. Model Response Units and drainage networks for the watershed models of the $(A)$ Pleasant, $(B)$ Narraguagus, (C) Sheepscot, and (D) Royal Rivers.-Continued 


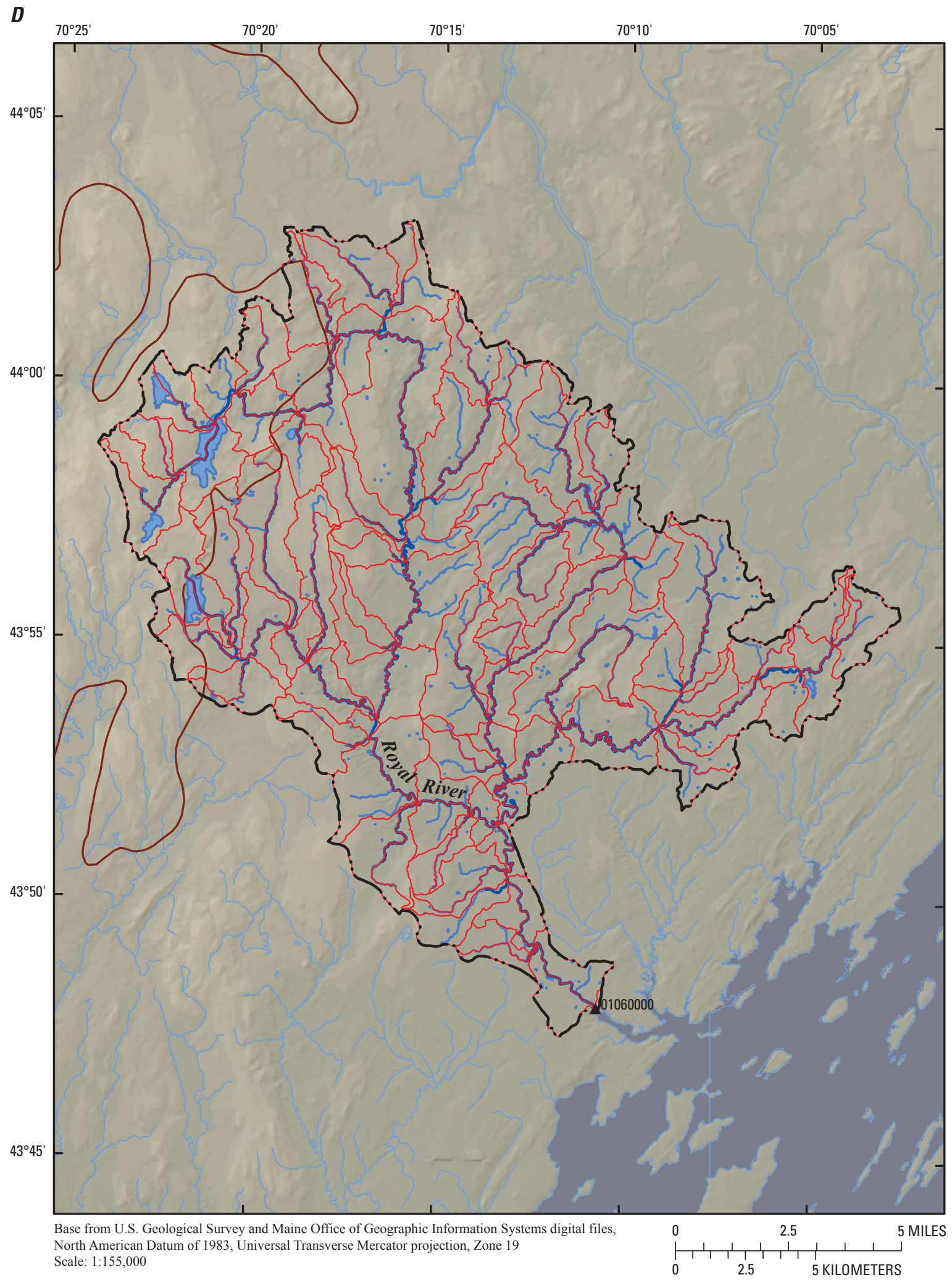

\section{EXPLANATION}

- $\cdots$ - Basin boundary

Model response unit

01060000 U.S. Geological Survey streamflow-gaging

Marine inundation limit

$\Delta \quad$ station and number

Figure 6. Model Response Units and drainage networks for the watershed models of the (A) Pleasant, $(B)$ Narraguagus, (C) Sheepscot, and (D) Royal Rivers.-Continued 
Table 5. Sources of values for selected Model Response Unit (MRU) (distributed) and whole-model (nondistributed) Precipitation Runoff Modeling System (PRMS) parameters for the study basins, Maine.

[GIS, derived from digital data sources using geographic information systems; Com., computed or estimated on the basis of climatological or hydrologic data or other related observations; Def., values as provided by Leavesley and others (1983); Cal., final value determined by way of calibration; MRU, modeling response unit; terms between parentheses indicate units of the value; day ${ }^{-1}$, per day; $\mathrm{F}^{-1}$, per degree Fahrenheit; inch ${ }^{-1}$, per inch; F, Fahrenheit; PET, potential evapotranspiration]

\begin{tabular}{|c|c|c|c|c|c|}
\hline \multirow{2}{*}{ Parameter } & \multirow{2}{*}{ Description (in [units of measure]) } & \multicolumn{4}{|c|}{ Source } \\
\hline & & GIS & Com. & Def. & Cal. \\
\hline \multicolumn{6}{|c|}{ Distributed (MRU-dependent) parameters } \\
\hline cov_type & Vegetation cover type. & $\mathrm{X}$ & & & \\
\hline covden_sum & Summer vegetation cover density (decimal fraction). & $\mathrm{X}$ & & & \\
\hline gwflow_coef & Groundwater routing coefficient; contribution to streamflow (in day ${ }^{-1}$ ). & & & & $\mathrm{X}$ \\
\hline gwsink_coeff & Groundwater sink coefficient (in day ${ }^{-1}$ ). & & & & $\mathrm{X}$ \\
\hline gwstor_init & Initial storage in each groundwater reservoir (in inches). & & & & $\mathrm{X}$ \\
\hline hru_area & MRU area (in acres). & $\mathrm{X}$ & & & \\
\hline hru_aspect & MRU compass-bearing exposure (in degrees). & $\mathrm{X}$ & & & \\
\hline hru_percent_imperv & MRU percent impervious area (decimal fraction). & $\mathrm{X}$ & & & \\
\hline hru_sfres & Index of surface reservoir. & $\mathrm{X}$ & & & \\
\hline hru_slope & MRU slope (vertical feet/horizontal feet; decimal fraction). & $\mathrm{X}$ & & & \\
\hline hru_ssres & Index of subsurface reservoir. & $\mathrm{X}$ & & & \\
\hline hru_type & Index differentiating between land and lake/reservoir MRU types. & $\mathrm{X}$ & & & \\
\hline jh_coef_hru & $\begin{array}{l}\text { MRU air temperature coefficient used in Jensen and Haise (1963) PET } \\
\text { computations (in degrees } \mathrm{F}^{-1} \text { ). }\end{array}$ & & $\mathrm{X}$ & & \\
\hline rad_trncf & $\begin{array}{l}\text { Transmission coefficient for short-wave radiation through the winter } \\
\text { vegetation canopy (decimal fraction). }\end{array}$ & & $\mathrm{X}$ & & \\
\hline snow_intcp & $\begin{array}{l}\text { Snow interception storage capacity for major vegetation type on MRU } \\
\text { (in inches). }\end{array}$ & $X$ & & & \\
\hline snowinfil_max & Maximum snow infiltration (in inches per day). & & & $\mathrm{X}$ & \\
\hline soil_moist_init & Initial value for available water in the soil profile (in inches). & $\mathrm{X}$ & & & \\
\hline soil_moist_max & Maximum water-holding capacity of the soil profile (in inches). & & & & $\mathrm{X}$ \\
\hline soil_rechr_init & Initial value for available water in the soil recharge zone (in inches). & $\mathrm{X}$ & & & \\
\hline soil_rechr_max & Maximum value for available water in the soil recharge zone (in inches). & & & & $\mathrm{X}$ \\
\hline soil_type & Index indicating MRU soil type. & $\mathrm{X}$ & & & \\
\hline soil2gw_max & $\begin{array}{l}\text { Maximum value for excess soil water routed to groundwater (in inches } \\
\text { per day). }\end{array}$ & & & & $\mathrm{X}$ \\
\hline srain_intcp & $\begin{array}{l}\text { Summer precipitation interception storage capacity for major vegetation } \\
\text { type on MRU (in inches). }\end{array}$ & $\mathrm{X}$ & & & \\
\hline ssr2gw_rate & Coefficient to route water from subsurface to groundwater (in days ${ }^{-1}$ ). & & & & $\mathrm{X}$ \\
\hline
\end{tabular}


Table 5. Sources of values for selected Model Response Unit (MRU) (distributed) and whole-model (nondistributed) Precipitation Runoff Modeling System (PRMS) parameters for the study basins, Maine.-Continued

[GIS, derived from digital data sources using geographic information systems; Com., computed or estimated on the basis of climatological or hydrologic data or other related observations; Def., values as provided by Leavesley and others (1983); Cal., final value determined by way of calibration; MRU, modeling response unit; terms between parentheses indicate units of the value; day ${ }^{-1}$, per day; $\mathrm{F}^{-1}$, per degree Fahrenheit; inch ${ }^{-1}$, per inch; F, Fahrenheit; PET, potential evapotranspiration]

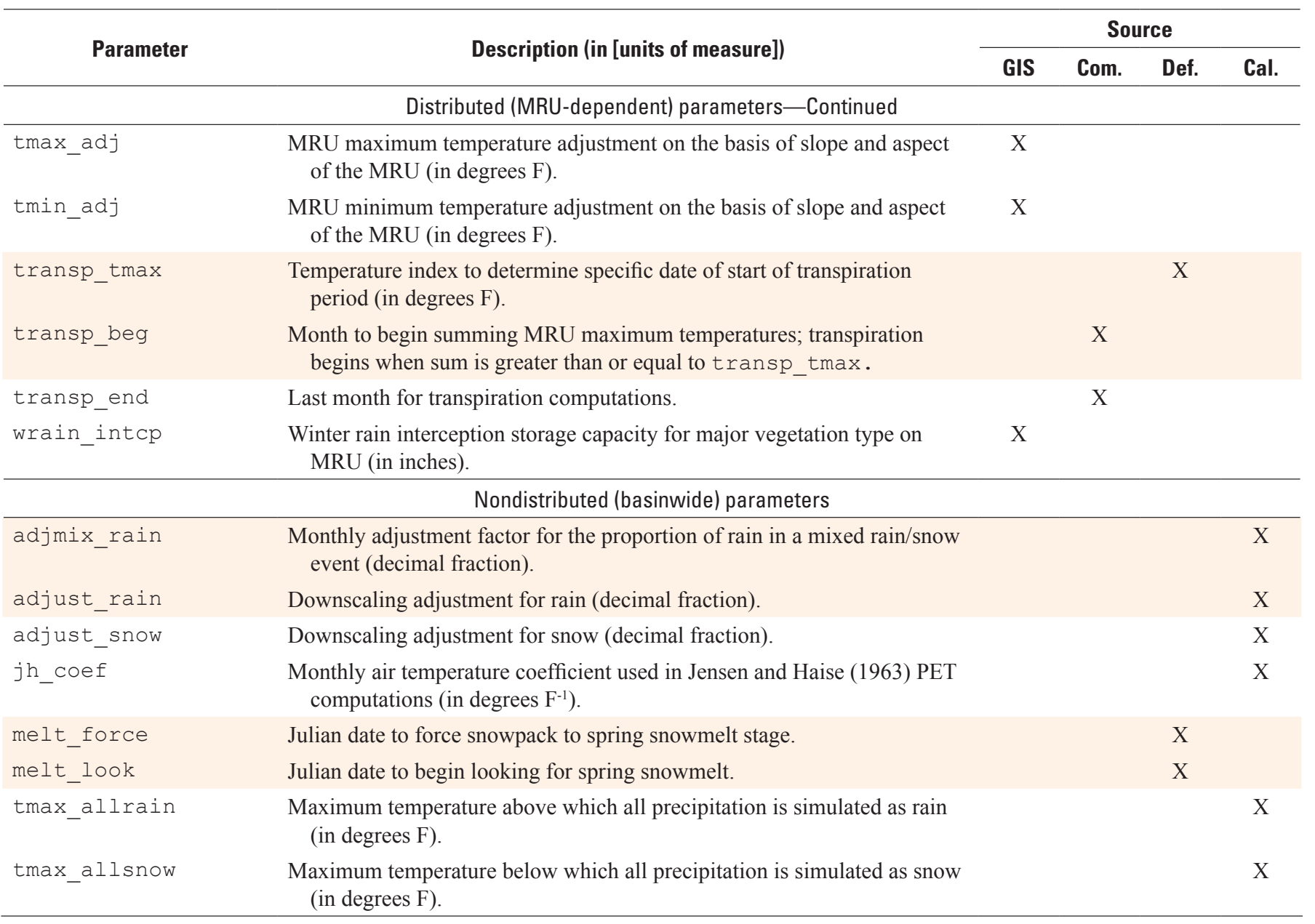


Table 6. Meteorological stations (National Oceanic and Atmospheric Administration's National Weather Service Cooperative Observer Program (NOAA COOP)) in the vicinity of the study basins from whose meteorological data (precipitation and maximum and minimum air temperature) multiple linear regressions (MLR) were derived to be spatially distributed within each study basin.

[USGS, U.S. Geological Survey]

\begin{tabular}{cll}
\hline $\begin{array}{c}\text { Study basin, } \\
\text { USGS streamgage }\end{array}$ & \multicolumn{1}{c}{$\begin{array}{c}\text { NOAA COOP stations providing meteorological data } \\
\text { (station identification numbers) }\end{array}$} & $\begin{array}{c}\text { Dependent daily meteorolog- } \\
\text { ical variable used for MLR }\end{array}$ \\
\hline Pleasant River, 01022260 & $170355,170398,171628,171975,173261,174183,176430$ & Precipitation \\
& $170355,170398,170480,171975,173261,174183,176430,178353,179891$ & Air temperature, maximum \\
& $170355,170398,170480,171975,173261,174183,176430,178353,179891$ & Air temperature, minimum \\
Narraguagus River, 01022500 & $170355,170398,171628,171975,173261,174183,176430$ & Precipitation \\
& $170355,170398,170480,171975,173261,174183,178353,179891$ & Air temperature, maximum \\
& $170355,170398,170480,171975,173261,174183,178353,179891$ & Air temperature, minimum \\
Sheepscot River, 01038000 & $170275,170480,170934,173046,174566,175675,176881,179151,179593$ & Precipitation \\
& $170275,170934,173046,174566,175675,179593$ & Air temperature, maximum \\
& $170275,170480,170934,172765,173046,175675,176881,179151,179593$ & Air temperature, minimum \\
Royal River, 01060000 & $170844,172238,173046,176905,179314$ & Precipitation \\
& $170275,170934,173046,174566,175675,176905$ & Air temperature, maximum \\
& $170275,170844,170934,172238,173046,175675,176881$ & Air temperature, minimum \\
\hline
\end{tabular}

\section{Calibration of the Watershed Models}

Following initial parameterization using the GIS Weasel, the four watershed models were sequentially calibrated to determine the values of parameters that cannot be directly measured. Calibration used a stepwise, multiple-objective method; that is, calibration was carried out in a step by step fashion, and each step involved maximizing or minimizing model output values (defined by objective functions) to most closely match values derived from measured data. This stepwise, multiple-objective calibration method follows a procedure documented by Hay and others (2006) in their application of PRMS to the Yampa River Basin in Colorado; the same method was adopted by Dudley (2008) in applying PRMS to the Dennys River Basin in Maine.

Calibration involved a four-step procedure in which model output was evaluated against four independent datasets by using computed objective functions. The objective functions enabled us to evaluate the fit between the simulated model output and measured values; the objective functions serve as criteria for the calibration. During each step, selected model parameters were calibrated by improving one or more associated objective functions. The values of the previously calibrated parameters were carried forward into the next calibration step. The four-step procedure was repeated until no further improvement was made in the simulation.

The four steps with associated calibration datasets and objective functions were (1) mean monthly solar radiation for the basin, with an objective function of the sum of the absolute difference in the logarithms of measured and of simulated solar radiation; (2) basin mean potential evapotranspiration, with an objective function of the sum of the absolute difference in the logarithms of measured and of simulated potential evapotranspiration; (3) annual and seasonal water balances, with multiple objective functions of the sums of the absolute value of the normalized residuals for each year and season; and (4) daily streamflow, with multiple objective functions of the normalized root mean square error for low streamflow (streamflow in the lowest quartile), high streamflow (streamflow in the highest quartile), intermediate streamflow (interquartile range), and all streamflow for the historical period of record (table 7).

The four-step calibration procedure described above involved thousands of model runs using the software application Luca (Let us calibrate) (Hay and Umemoto, 2006; Umemoto and others, 2006). Luca provides a user-friendly, systematic method for building and executing user-defined calibration procedures for any model constructed with MMS. Luca uses the Shuffled Complex Evolution (SCE) global search algorithm (Duan and others, 1994) to calibrate the model parameters; results of experimental studies indicate that the SCE method reliably produces satisfactory solutions for large complex optimization problems (Duan and others, 1994). Dudley (2008) used Luca to calibrate PRMS models of the Dennys River and Cathance River Basins, Maine, with satisfactory results. 
Table 7. Interquartile ranges (IOR) defining the threshold streamflow values delineating low (below the IQR), high (above the $I Q R$ ), and intermediate (within the IOR, inclusive) streamflow regimes for each study basin (step 4 of the calibration procedure outlined in the section, "Calibration of the Watershed Models").

[USGS, U.S. Geological Survey; $\mathrm{ft}^{3} / \mathrm{s}$, cubic feet per second; Statistics for Pleasant River, USGS station number 01022260, were computed on the basis of daily mean streamflow data collected during calendar years 1980-91, 2001-08; for Narraguagus River, 01022500, on the basis of data during 1948-2008; for Sheepscot River, 01038000, on the basis of data during 1938-2008; and for Royal River, 01060000, on the basis of data during 1949-2004]

\begin{tabular}{clc}
\hline Number & \multicolumn{1}{c}{ Name } & $\begin{array}{c}\text { Interquartile } \\
\text { range } \\
\left(\mathbf{f t}^{3} / \mathbf{s}\right)\end{array}$ \\
\hline 01022260 & Pleasant River near Epping & $53-194$ \\
01022500 & Narraguagus River at Cherryfield & $141-625$ \\
01038000 & Sheepscot River at North Whitefield & $49-322$ \\
01060000 & Royal River at Yarmouth & $62-280$ \\
\hline
\end{tabular}

The Nash-Sutcliffe efficiency (NSE) statistic (equation 2) was used as a measure of model performance for the four basins in this study; it is a normalized statistic that provides a measure of how well simulated output matches measured data (Moriasi and others, 2007; Nash and Sutcliffe, 1970):

$$
N S E=\left[1-\frac{\frac{1}{n} \sum_{i=1}^{n}\left(Q_{o b s, i}-Q_{s i m, i}\right)^{2}}{\frac{1}{n} \sum_{i=1}^{n}\left(Q_{o b s, i}-\bar{Q}_{o b s, i}\right)^{2}}\right] .
$$

where

$$
\begin{aligned}
Q_{o b s, i} & \text { is the } i \text { th measurement for basin streamflow, } \\
Q_{s i m, i} & \text { is the } i \text { th simulated basin streamflow, } \\
\bar{Q}_{o b s, i} & \text { is the mean of the measured basin streamflow, } \\
& \text { and } \\
& \text { is the total number of measurements. }
\end{aligned}
$$

NSE ranges in value from negative infinity through 1.0; a value of 0.0 or less indicates that the mean measured streamflow is a better predictor than the simulated streamflow; and values between 0.0 and 1.0 are viewed as acceptable, with 1.0 indicating a perfect match between every measured and simulated streamflow value (Moriasi and others, 2007).

\section{Simulation of Streamflow in the Pleasant, Narraguagus, Sheepscot, and Royal Rivers, Maine}

This section describes the results of the SCE calibration procedure for the watershed models of the Pleasant, Narraguagus, Sheepscot, and Royal Rivers. All four models were calibrated and evaluated using measured streamflow for two different historical periods. The calibration involved adjusting the model parameters to match measured streamflow during the calibration period. The evaluation involved comparing modeled streamflow to measured streamflow without any adjustment of model parameters.

The first step in the four-step Luca calibration procedure involved basin mean monthly solar radiation (SR). Modeled estimates of SR as a function of daily shortwave radiation, estimated from daily air temperature data and time of the solar year, adjusted by the slope and aspect (topography) for each MRU. In general, the calibrated models yielded simulated SR close to the calibration data (fig. 7). Evaluation values were satisfactory, with deviations from interpolated values being a function of the variability in air temperature data available for input for the evaluation periods.

The second step in the SCE calibration procedure involved basin mean monthly potential evapotranspiration (PET). Modeled estimates of PET are computed using daily mean air temperature and daily solar radiation by following a procedure developed by Jensen and Haise (1963); the monthly variability in modeled PET results for the evaluation period thus closely resembles that for solar radiation. Simulated potential evapotranspiration values generally agreed with values calculated from PET maps (fig. 8). Simulated values from the evaluation period were likewise satisfactory.

The third step in the SCE calibration procedure related simulated annual and seasonal water volumes to basin runoff volumes measured at the downstream streamgages. Seasonal runoff volumes were defined as total runoff for the months associated with the four seasons: winter-December, January, February; spring-March, April, May; summer-June, July, August; autumn - September, October, November.

For the Pleasant River Basin, runoff for the 11-year calibration period was 0.0 percent different from measured runoff; 9 of the 11 years were less than 10 percent different (fig. 9A). Total runoff for the 7-year evaluation period was -15.3 percent different from measured runoff (fig. 9B); 4 of the 7 years were within 10.2 percent different from measured runoff (fig. 9B). Calibrated seasonal runoff volumes ranged from 1.9 percent different (spring) to -13.1 percent different (winter) from measured runoff (fig. 9A); evaluation seasonal runoff volumes ranged from -8.7 percent different (autumn) to -25.0 percent different (summer) from measured runoff (fig. 9B).

For the Narraguagus River Basin, runoff for the 17-year calibration period was 0.6 percent different from measured runoff; 15 of the 17 years were 10 percent or better different 

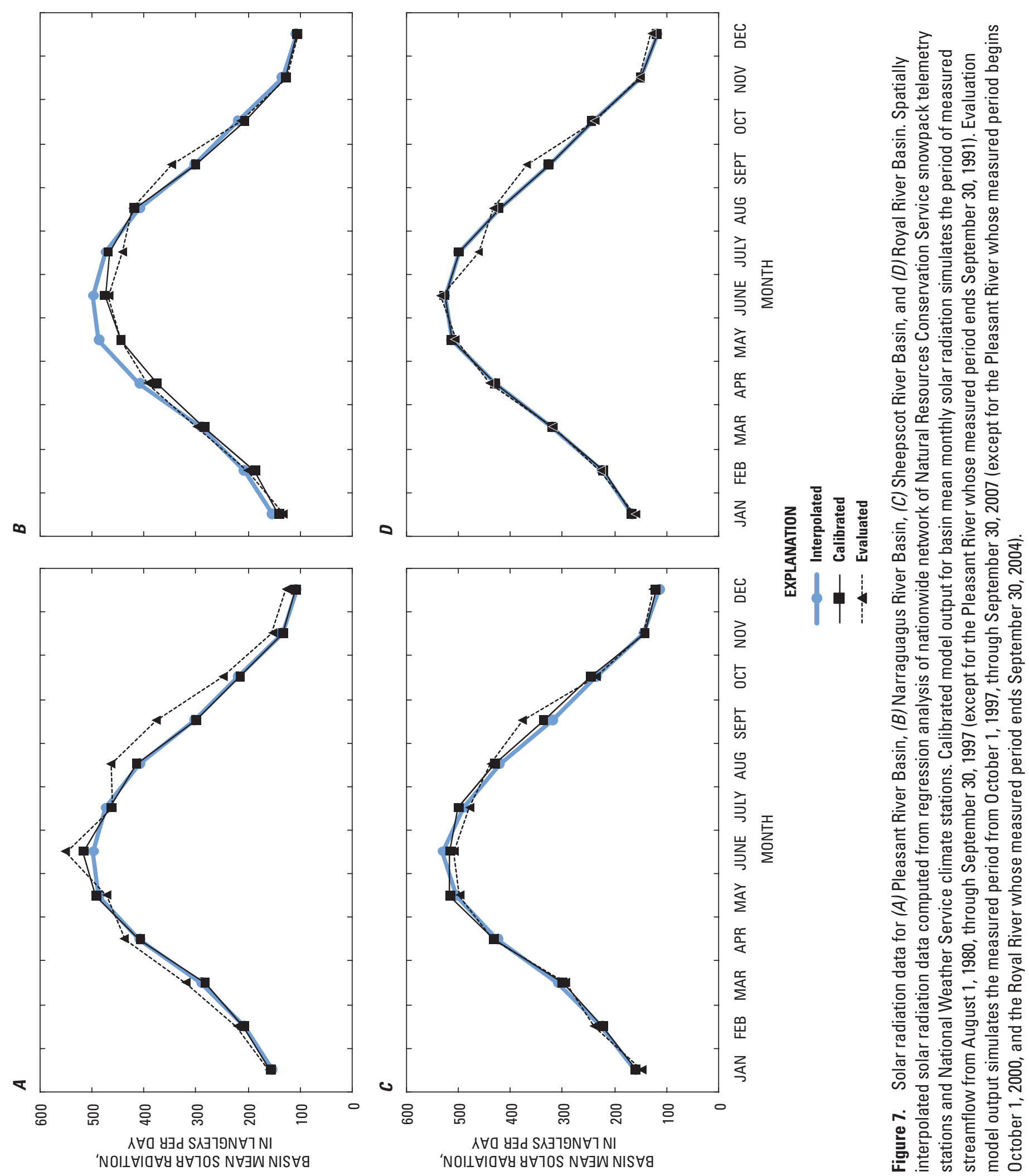

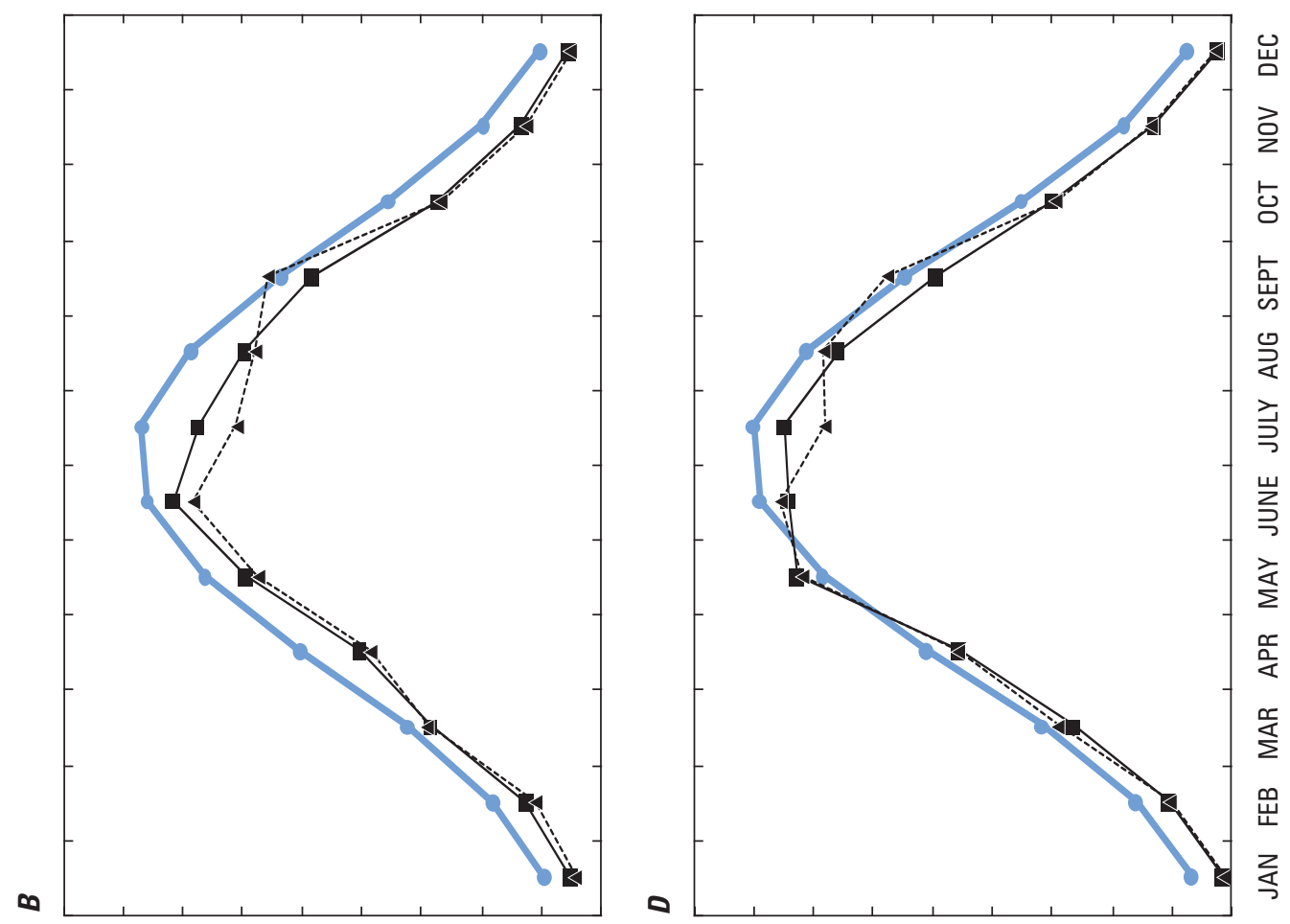

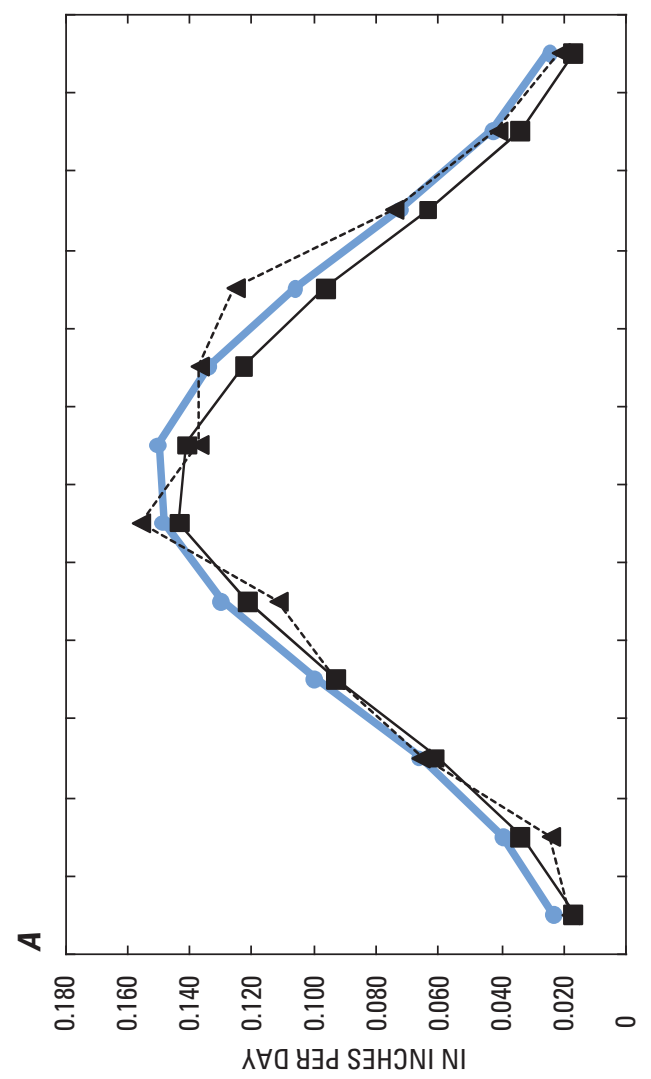

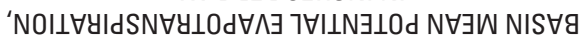

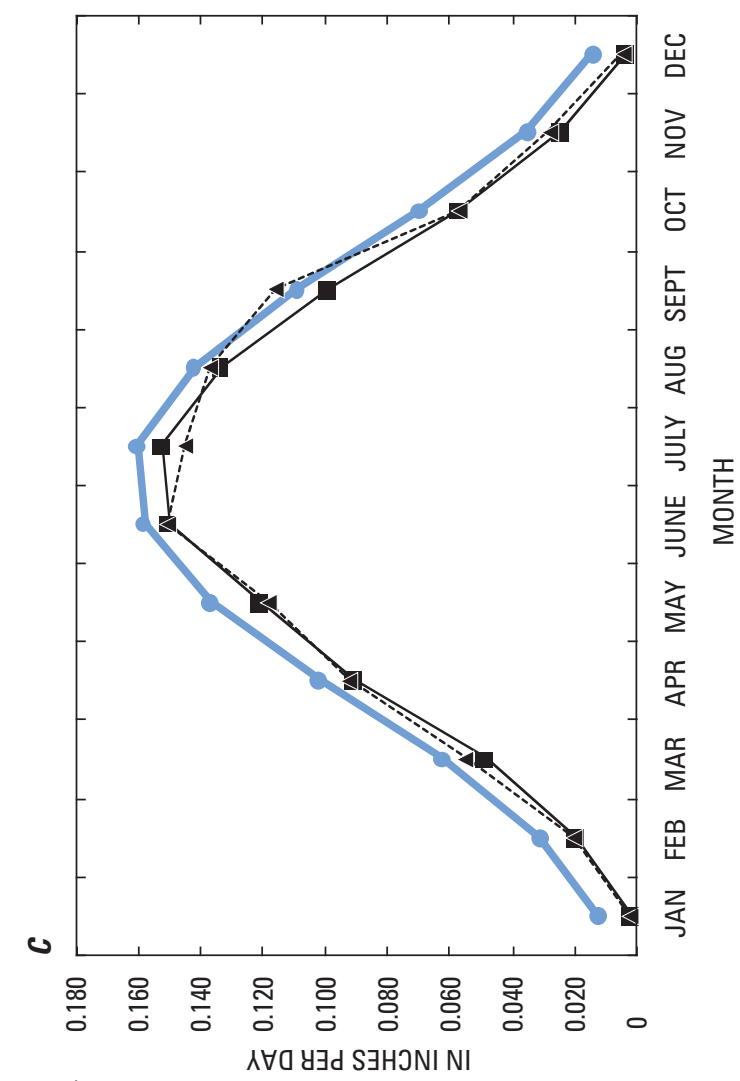

'NOII $\forall Y I d S N \forall Y \perp O d \forall A \exists 7 \forall I \perp N \exists \perp O d$ N $\forall \exists W N I S \forall g$

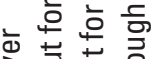

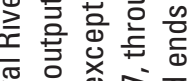

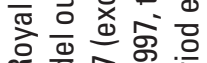

등 응 㐫

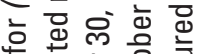

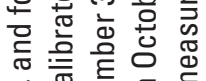

元

क बं 응 유 용

ص.

㐫

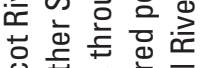

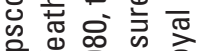

๙ ॐ

它 $\bar{\sigma}=$

心.을

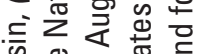

ॠ

๘

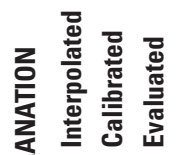

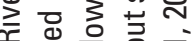

क

중

亭京离

章

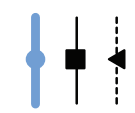

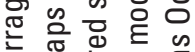

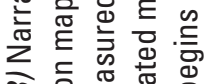

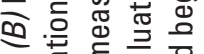

돈.

匹

훈

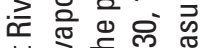

过

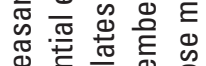

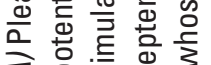

증

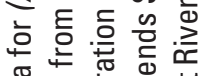

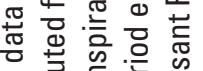

ᄃ

흥ㅎㅁ응음

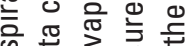

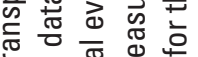

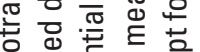

능 क्ष

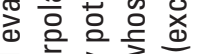

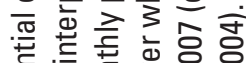

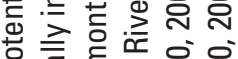

.

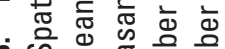

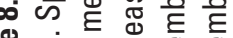

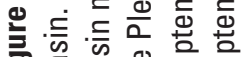

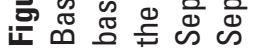




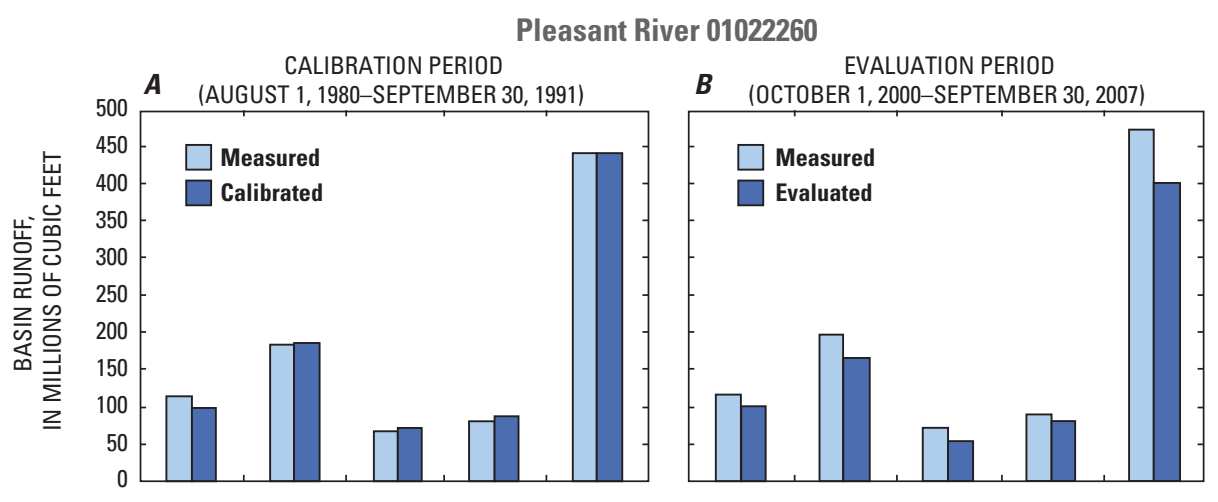

Narraguagus River 01022500

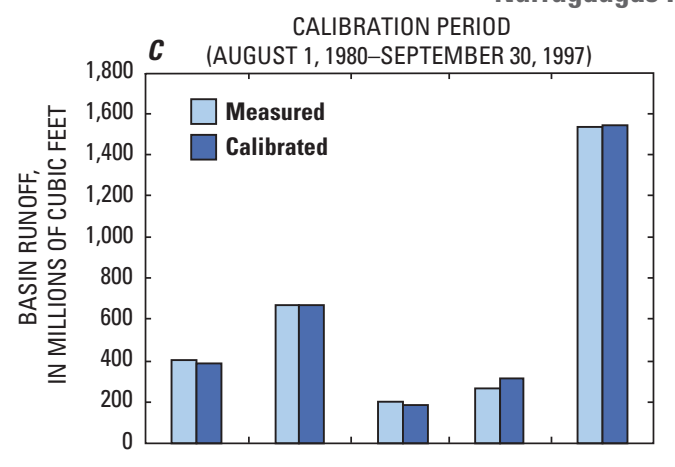

EVALUATION PERIOD

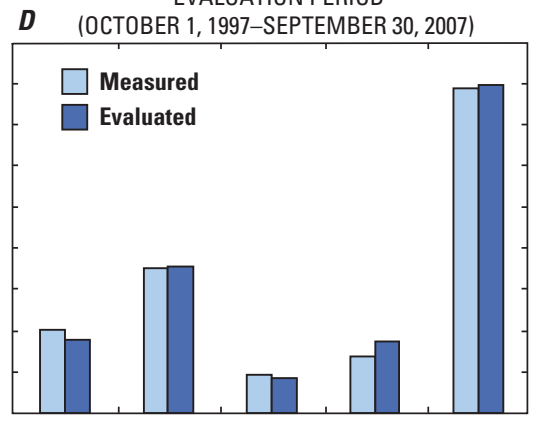

Sheepscot River 01038000

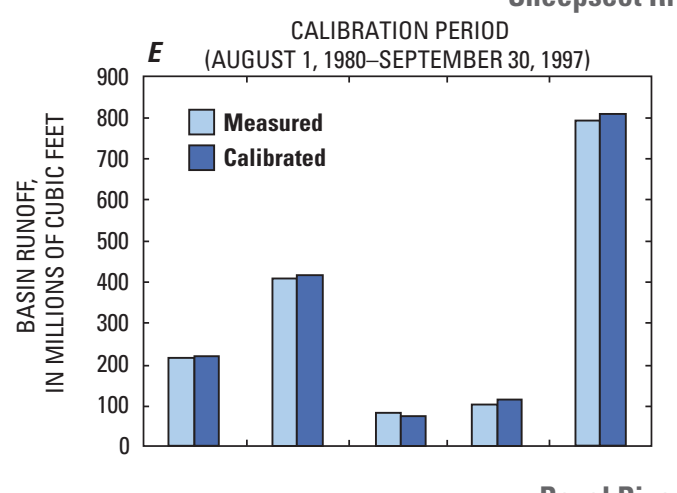

EVALUATION PERIOD F (OCTOBER 1, 1997-SEPTEMBER 30, 2007)

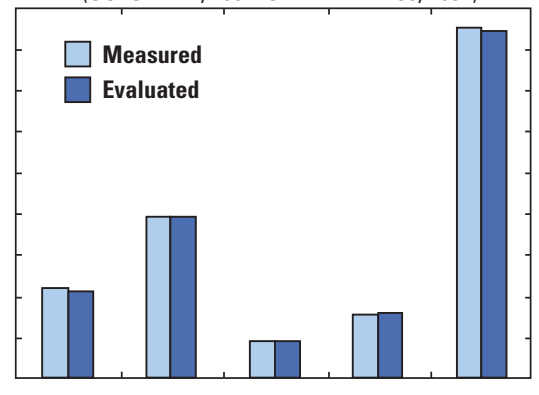

CALIBRATION PERIOD
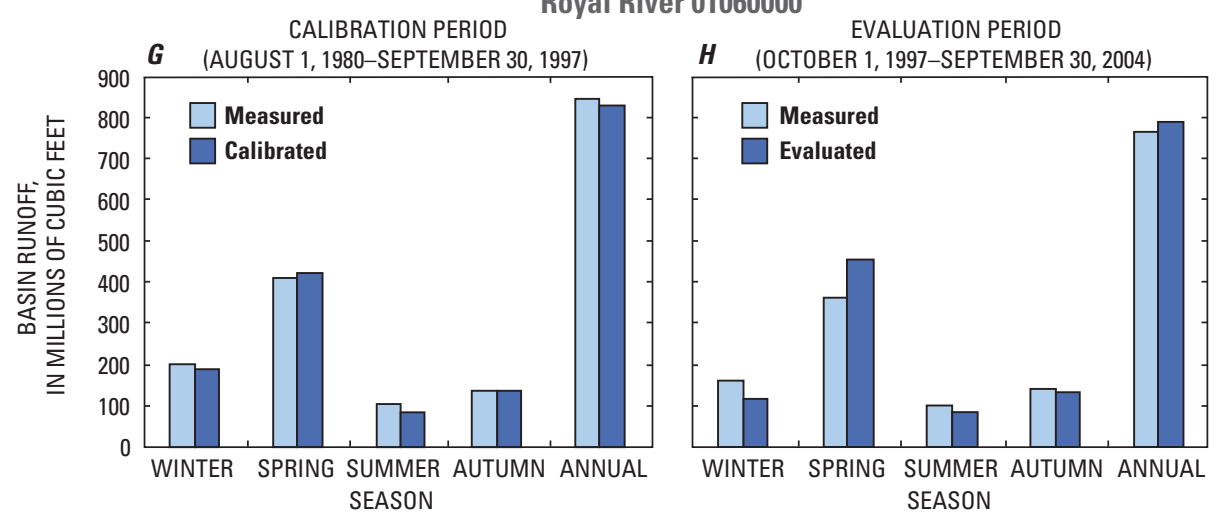

Figure 9. (A) Pleasant River Basin calibrated model output for mean seasonal and annual outflow volumes simulating the measured period from August 1, 1980, through September 30, 1991; (B) Pleasant River Basin evaluation model output simulating the measured period from 0 ctober 1,2000 , through September 30, 2007; (C) Narraguagus River Basin calibrated model output for mean seasonal and annual outflow volumes simulating the measured period from August 1, 1980, through September 30, 1997; (D) Narraguagus River Basin evaluation model output simulating the measured period from October 1, 1997, through September 30, 2007; (E) Sheepscot River Basin calibrated model output for mean seasonal and annual outflow volumes simulating the measured period from August 1, 1980, through September 30, 1997;

(F) Sheepscot River Basin evaluation model output simulating the measured period from October 1, 1997, through September 30, 2007; (G) Royal River Basin calibrated model output for mean seasonal and annual outflow volumes simulating the measured period from August 1, 1980, through September 30, 1997; and (H) Royal River Basin evaluation model output simulating the measured period from October 1, 1997, through September 30, 2004. 
from measured runoff (fig. 9C). Total runoff for the 10-year evaluation period was 1.0 percent different from measured runoff; 5 of the 10 years were 10.3 percent or better different from measured runoff (fig. 9D). Calibrated seasonal runoff volumes ranged from -0.5 percent different (spring) to 16.7 percent different (autumn) from measured runoff (fig. 9C); evaluation seasonal runoff volumes ranged from 0.5 percent different (spring) to 25.9 percent different (autumn) from measured runoff (fig. 9D).

For the Sheepscot River Basin, runoff for the 17-year calibration period was 2.0 percent different from measured runoff; 13 of the 17 years were 10 percent or better different from measured runoff (fig. 9E). Total runoff for the 10-year evaluation period was -1.1 percent different from measured runoff; 7 of the 10 years were 10 percent or better different from measured runoff (fig. 9F). Calibrated seasonal runoff volumes ranged from 1.6 percent different (winter) to -12.3 percent different (summer) from measured runoff (fig. 9E); evaluation seasonal runoff volumes ranged from -0.4 percent different (spring) to -4.8 percent different (winter) from measured runoff (fig. 9F).

For the Royal River Basin, runoff for the 17-year calibration period was -1.9 percent different from measured runoff; 13 of the 17 years were 10.5 percent or better different from measured runoff (fig. 9G). Total runoff for the 7-year evaluation period was 3.3 percent different from measured runoff; 6 of the 7 years were 10 percent or better different from measured runoff (fig. 9H). Calibrated seasonal runoff volumes ranged from 0.4 percent different (autumn) to -19.5 different (summer) from measured runoff (fig. 9G); evaluation seasonal runoff volumes ranged from -4.6 percent different (autumn) to -25.7 percent different (winter) from measured runoff (fig. 9H).

The fourth step in the SCE calibration procedure related simulated daily streamflow to basin runoff measured at the downstream streamgages (fig. 10). The objective of the calibration was to minimize differences between simulated and measured daily low, high, and intermediate streamflow. In a few cases, when several days or weeks correlated poorly (fig. 10) as a result of a mismatch between modeled meteorological inputs to the basin and what actually happened in the basin (see "Watershed Model Results, Uncertainties, and Limitations" section), NSE values for the calibration and evaluation periods ranged from 0.55 to 0.75 , indicating satisfactory simulations overall (table 8).

The Pleasant River Basin (figs. 10A and B) model tended to underestimate low streamflow during the calibration and evaluation periods. This is most likely a result of inadequately modeling the storage effects of the Great Heath located just upstream from the USGS streamgage. Future work with this model should involve explicit modeling of the storage capacity of the Great Heath using the recently developed lakes module for PRMS (Dudley, 2008). The models for the Narraguagus River Basin (figs. 10C and D), Sheepscot River Basin (figs. 10E and F), and Royal River Basin (figs. 10G and H) models generally performed satisfactorily, except for a few cases when several days or weeks correlated poorly as a result of a mismatch between meteorological data inputs to the model and what actually meteorologically transpired in the basin.

\section{Results, Uncertainties, and Limitations of the Watershed Models}

The PRMS watershed models require data on precipitation and air temperature as input to drive the computations; thus, the models are highly dependent on the accuracy of those data. In this study, precipitation data were largely derived from a relatively sparse network of NWS meteorological stations. Precipitation records used in this investigation provided a point coverage in and around the basins of interest, and were interpolated to provide an areal distribution of precipitation within the modeled basins. Actual rainfall can vary greatly over small distances; thus, the available precipitation dataset used in this investigation contributed to imprecise matches between simulated streamflow and measured streamflow on an event-by-event basis.

Temperature records were similarly derived from the relatively sparse network of NWS meteorological stations. Temperature data have a significant effect on simulated runoff; the data are used in computations of solar radiation, and therefore, in computations of evapotranspiration. Air temperatures are a controlling factor in determining the form of precipitation (rain, snow, or mixture of both) and whether existing snowpack accumulates or melts, thereby directly affecting the timing and amount of precipitation released from frozen-water storage in the basins. Thus, just as did the precipitation dataset used in this investigation, the temperature dataset contributed to imprecise matches between simulated streamflow and measured streamflow on an event-by-event basis.

The computation of runoff by PRMS is a rudimentary accounting of streamflow at the MRU (subbasin) scale rather than a rigorous simulation of the hydraulics of water movement; the location and velocity of channelized runoff within any subbasin is not explicitly modeled, nor are mechanisms such as gains from and losses to groundwater through the streambed in any given reach.

The lack of groundwater data in the study basins introduces uncertainties in the models because there was little to no information available to guide the proper modeling of groundwater flow throughout the basin. Despite the lack of groundwater data and associated uncertainties, the models could calibrate simulated streamflow to measured streamflow thereby providing a first-cut estimate of the relative amounts of surface-water and groundwater contributions to streamflow throughout the basin. With more groundwater data, and with intensive, explicit modeling of interactions between groundwater and surface water by using GSFLOW, subsequent studies can very probably improve the performance of the four study basin models. GSFLOW is a coupled groundwater and surface-water flow model based on the integration 


\section{Pleasant River 01022260}
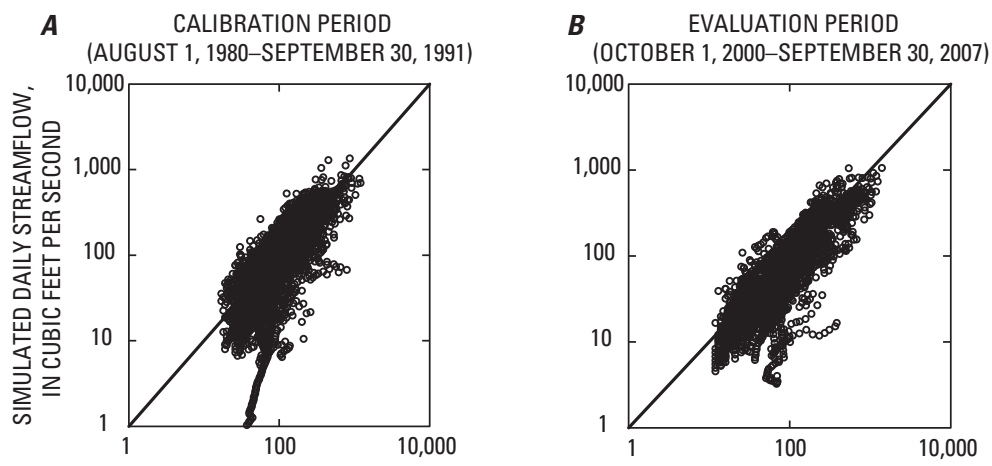

Narraguagus River 01022500
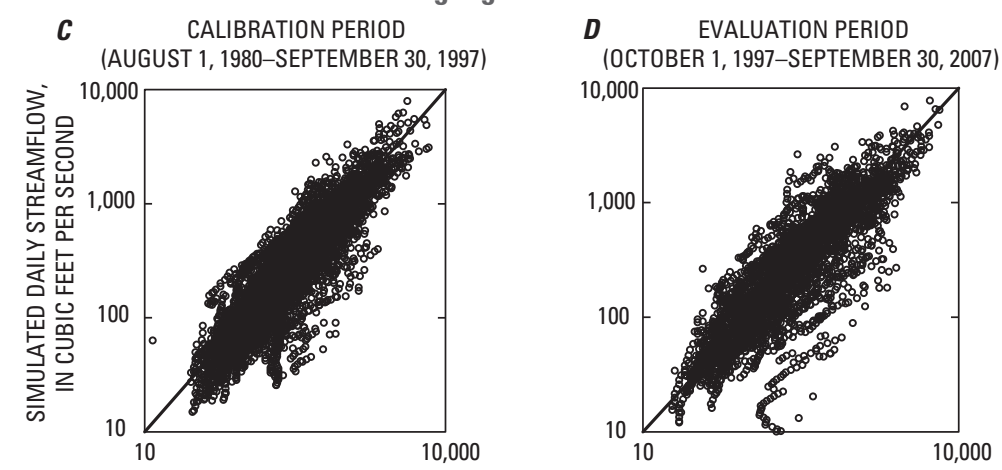

Sheepscot River 01038000
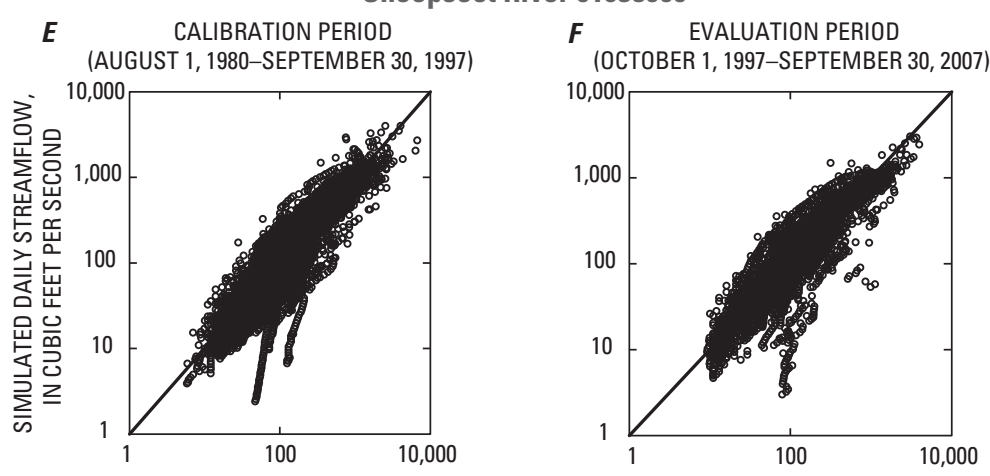

Royal River 01060000
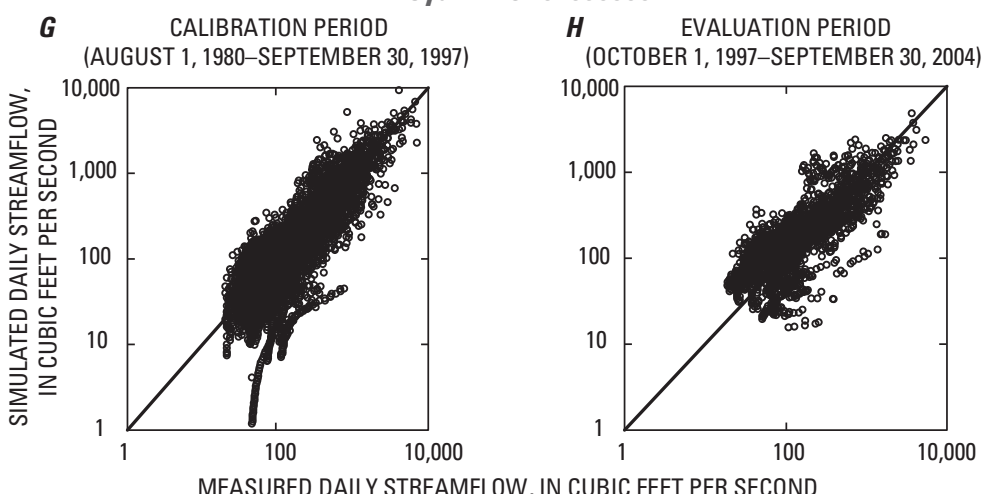

Figure 10. Calibration and evaluation model output for all daily streamflow for the Pleasant River Basin $(A, B)$, Narraguagus River Basin $(C, D)$, Sheepscot River Basin ( $E, F)$, and Royal River Basin $(G, H)$. Calibrated model output for daily streamflow simulates the measured period from August 1, 1980, through September 30, 1997 (except for the Pleasant River Basin whose measured period ends September 30, 1991. Evaluated model output simulates the measured period from October 1, 1997, through September 30, 2007 (except for the Pleasant River Basin whose measured period begins 0ctober 1, 2000, and the Royal River Basin whose measured period ends September 30, 2004). 
Table 8. Nash-Sutcliffe efficiency (NSE) statistics for calibration and evaluation model runs for each study basin, coastal Maine.

[USGS, U.S. Geological Survey; NSE value is a measure, between negative infinity and 1.0, of the extent to which output simulated by the model matches measured data]

\begin{tabular}{cccc}
\hline & USGS streamgage & \multicolumn{2}{c}{$\begin{array}{c}\text { NSE value } \\
\text { (range: nega- } \\
\text { tive infinity } \\
\text { to 1.0) }\end{array}$} \\
\hline Number & Name & $\begin{array}{c}\text { Cali- } \\
\text { bration }\end{array}$ & $\begin{array}{c}\text { Evalu- } \\
\text { ation }\end{array}$ \\
\hline 01022260 & Pleasant River near Epping & 0.59 & 0.69 \\
01038000 & Sheepscot River at North Whitefield & 0.75 & 0.73 \\
\hline
\end{tabular}

of PRMS and the Modular Groundwater Flow Model (MODFLOW-2005) (Markstrom and others, 2008).

Overall, the basin models constructed in this investigation performed satisfactorily, with the weakest simulations occurring during periods of extremely low streamflow and during the winter months. Some periods of unsatisfactory performance of the models during winter months could be due to sensitivity of the models to air temperature data and the difficulty in properly modeling rain, snow, or mixed-phase precipitation events. The models may also be sensitive to the changing permeability of frozen soils during cold periods.

Spatially and temporally explicit characterization of hydrologic conditions throughout each of the study basins will lead to a better understanding of water quantity and quality and will support the planning and execution of ongoing and future efforts to protect Atlantic salmon. Calibrated watershed models can be used as tool to support a variety of crossdiscipline and resource-management investigations and the decision making associated with such investigations.

\section{Summary}

Four watersheds in coastal Maine (Pleasant, Narraguagus, Sheepscot, and Royal River Basins) were simulated using the USGS Precipitation Runoff Modeling Systems (PRMS) to investigate anticipated changes in summer streamflow and stream temperatures and the potential effects of those changes on endangered Atlantic salmon populations. PRMS is a deterministic, distributed-parameter modeling system that simulates daily streamflow, given inputs of daily minimum and maximum temperature and daily precipitation. Development of these models helps advance the comprehensive recovery programs for endangered species developed by the National Marine Fisheries Service and U.S. Fish and Wildlife Service. These models also advance the development of watermanagement plans for each of the four river basins that are home to protected Atlantic salmon.

Parameters for the geographic features of the study basins and subbasins were derived using the GIS Weasel and the U.S. General Soil Map, North American Land Cover Characteristics Data Base, U.S. Forest Type Groups, and U.S. Forest Density maps, and a digital elevation model (DEM) and its derivative surfaces. Parameters derived for each subbasin (modeling response unit (MRU)) include: area, elevation, slope, aspect, vegetation type and density, intercepting capacities for precipitation, and soil types.

The stepwise, multiple-objective calibration method used in the development of the watershed models followed a fourstep procedure in which model outputs were evaluated against four calibration datasets using mathematical optimization for solar radiation, potential evapotranspiration, annual and seasonal water balances, and daily streamflow. The calibration procedure involved thousands of model runs and was carried out using the software application Luca, which provides a user-friendly, systematic way to build and execute user-defined calibration procedures for any model constructed with USGS Modular Modeling System (MMS). Luca used the shuffled complex evolution global search algorithm to optimize model parameters.

Models for the study basins were calibrated using 17 years of streamflow data collected from August 1, 1980, through September 30, 1997, except for the Pleasant River Basin which ends September 30, 1991. Ten years of streamflow record from October 1, 1997, through September 30, 2007, were used as an evaluation dataset, except for the Pleasant River Basin, the record for which begins October 1, 2000, and the Royal River Basin, the record for which ends September 30, 2004.

The calibrated watershed models simulate daily streamflow at many locations in each study basin. These models enable natural-resources managers to characterize the timing and amount of streamflow to support a variety of waterresources efforts, including water-quality calculations, assessments of water use, modeling of population dynamics and migration of Atlantic salmon, modeling and assessment of habitat, and simulation of anticipated changes to streamflow and water temperature resulting from forecasted changes in precipitation and in air temperatures.

The watershed models performed well, with the weakest simulations occurring during periods of extremely low streamflow and during the winter months. Some unsatisfactory performance of the models during the winter months could be due to sensitivity of the models to air temperature data, the difficulty in properly modeling rain, snow, or mixed precipitation events, and possible sensitivity to the changing permeability of soils during cold periods. 
PRMS watershed models require data on precipitation and air temperature as input to drive the computations; thus, the models are highly dependent on the accuracy of those data. In this study, precipitation and temperature data were largely derived from a relatively sparse National Weather Service (NWS) meteorological data network. The computation of streamflow by PRMS is a rudimentary accounting of streamflow at the subbasin scale, and not a rigorous simulation of the hydraulics of water movement; the location and velocity of channelized runoff within any subbasin is not explicitly modeled, nor are mechanisms such as gains from and losses to groundwater through the streambed in any given reach.

The lack of groundwater data in the study basins introduced uncertainties in the models because there was little to no information available to guide the modeling of groundwater flow throughout the basins. Nevertheless, these watershed models simulated streamflow calibrated to measured streamflow provide a first-cut estimate at quantifying relative amounts of surface-water and groundwater contributions to streamflow throughout the watersheds.

\section{Acknowledgments}

The authors thank the USGS watershed modeling group - Lauren Hay, Steve Markstrom, Steve Regan, and Roland Viger for helpful technical support, advice, and guidance. Reviews by Glenn Hodgkins, Katherine Chase, and Alice Koller, USGS, resulted in scientific and editorial improvements in this report.

\section{References Cited}

Ahearn, D.S., Sheibley, R.W., and Dahlgren, R.A., 2005, Effects of river regulation on water quality in the lower Mokelumne River, California: River Research and Applications, v. 21, p. 651-670.

Djokic, D., 2008, Comprehensive terrain preprocessing using Arc Hydro Tools, ESRI: Redlands, Calif., 61 p.

Duan, Q., Sorooshian, S., and Gupta, V.K., 1994, Optimal use of the SCE-UA global optimization method for calibrating watershed models: Journal of Hydrology, v. 158, p. 265-284.

Dudley, R.W., 2008, Simulation of the quantity, variability, and timing of streamflow in the Dennys River Basin, Maine, by use of a precipitation-runoff watershed model: U.S. Geological Survey Scientific Investigations Report 2008$5100,44 \mathrm{p}$.
Dudley R.W., and Hodgkins, G.A., 2002, Trends in streamflow, river ice, and snowpack for coastal river basins in Maine during the 20th century, U.S. Geological Survey Water-Resources Investigations Report 02-4245, 26 p.

Dudley, R.W., Hodgkins, G.A., and Letcher, B.H., 2008, Impacts of low-flow and stream-temperature changes on endangered Atlantic salmon — current research: U.S. Geological Survey Fact Sheet 2008-3044, 4 p.

Ely, D.M., 2003, Precipitation-runoff simulations of current and natural streamflow conditions in the Methow River Basin, Washington: U.S. Geological Survey WaterResources Investigations Report 03-4246, 35 p.

Ely, D.M., and Risley, J.C., 2001, Use of a precipitation-runoff model to simulate natural streamflow conditions in the Methow River Basin, Washington: U.S. Geological Survey Water-Resources Investigations Report 01-4198, 36 p.

Farnsworth, R.K., Thompson, E.S., and Peck, E.L., 1982, Evaporation atlas for the contiguous 48 United States: U.S. Department of Commerce, National Oceanic and Atmospheric Administration Technical Report NWS 33, 37 p.

Fontaine, R.A., 1978, Drainage areas of surface-water bodies of the Royal and Presumpscot River Basins in southwestern Maine: U.S. Geological Survey Open-File Report 78-556A, $54 \mathrm{p}$.

Fontaine, R.A., 1982a, Drainage areas of surface-water bodies of eastern Maine coastal river basins: U.S. Geological Survey Open-File Report 78-556H, 54 p.

Fontaine, R.A., 1982b, Drainage areas of surface-water bodies of central Maine coastal river basins: U.S. Geological Survey Open-File Report 78-556I, 54 p.

Fontaine, R.A., 1987, Application of a precipitation-runoff modeling system in the Bald Mountain area, Aroostook County, Maine: U.S. Geological Survey Water-Resources Investigations Report 87-4221, 49 p.

Hay, L.E., Clark, M.P., and Leavesley, G.H., 2000, Use of atmospheric forecasts in hydrologic models, Part Two: Case Study, in Kand, D.L., ed. Water resources in extreme environments: Middleburg, Va., American Water Resources Association, p. 221-226.

Hay, L.E., Leavesley, G.H., Clark, M.P., Markstrom, S.L., Viger, R.J., and Umemoto, M., 2006, Stepwise, multipleobjective calibration of a hydrologic model for a snowmeltdominated basin: Journal of the American Water Resources Association, v. 42, no. 4, p. 877-890.

Hay, L.E., and Umemoto, M., 2006, Multiple-objective stepwise calibration using Luca: U.S. Geological Survey Open-File Report 2006-1323, 25 p. 
Hayhoe, K., Wake, C.P., Huntington, T.G., Luo, L., Schwartz, M., Sheffield, J., Wood, E., Anderson, B., Bradbury J., DeGaetano, A., Troy, T., and Wolfe, D., 2007, Past and future changes in climate and hydrological indicators in the U.S. Northeast: Climate Dynamics, v. 28, p. 381-407.

Hejl, H.R., Jr., 1989, Application of the precipitation-runoff modeling system to the Ah-shi-sle-pah Wash watershed, San Juan County, New Mexico: U.S. Geological Survey WaterResources Investigations Report 88-4140, 36 p.

Helsel, D.R., and Hirsch, R.M., 1992, Statistical methods in water resources: New York, Elsevier, 522 p.

Hodgkins, G.A., and Dudley, R.W., 2006a, Changes in the timing of winter-spring streamflows in eastern North America, 1913-2002: Geophysical Research Letters, v. 33, L06402, doi:10.1029/2005GL025593, 5 p.

Hodgkins, G.A., and Dudley, R.W., 2006b, Changes in latewinter snowpack depth, water equivalent, and density in Maine, 1926-2004: Hydrological Processes, v. 20, p. 741-751.

Hodgkins, G.A., Dudley, R.W., and Huntington, T.G., 2005, Changes in the number and timing of days of ice-affected flow on northern New England rivers, 1930-2000: Climatic Change, v. 71, p. 319-340.

Hodgkins, G.A., James, I.C., and Huntington, T.G., 2002, Historical changes in lake ice-out dates as indicators of climate change in New England, 1850-2000: International Journal of Climatology, v. 22, p. 1819-1827.

Hodgkins, G.A., Lent, R.M., Dudley, R.W., and Schalk, C.W., 2009, Framework for a U.S. Geological Survey hydrologic climate-response program in Maine: U.S. Geological Survey Open-File Report 2009-1115, 29 p.

Hunter, L.E., and Smith, G.W., 2001, Morainal banks and the deglaciation of coastal Maine, in Weddle, T.K., and Retelle, M.J., eds., Deglacial history and relative sea-level changes, Northern New England and adjacent Canada: Boulder, Colo., Geological Society of America Special Paper 351, p. $151-170$.

Huntington, T.G., Hodgkins, G.A., Keim, B.D., and Dudley, R.W., 2004, Changes in the proportion of precipitation occurring as snow in New England (1949 to 2000): Journal of Climate, v. 17, p. 2626-2636.

Irland, L.C., 1998, Maine's forest area, 1600-1995-Review of available estimates: Maine Agricultural and Forest Experiment Station Miscellaneous Publication 736, 12 p.

Jensen, M.E., and Haise, H.R., 1963, Estimating evapotranspiration from solar radiation: Proceedings of the American Society of Civil Engineers, Journal of Irrigation and Drainage, v. 89, no. IR4, p. 15-41.
Jeton, A.E., 1999a, Precipitation-runoff simulations for the Lake Tahoe Basin, California and Nevada: U.S. Geological Survey Water-Resources Investigations Report 99-4110, $61 \mathrm{p}$.

Jeton, A.E., 1999b, Precipitation-runoff simulations for the upper part of the Truckee River Basin, California and Nevada: U.S. Geological Survey Water-Resources Investigations Report 99-4282, 41 p.

Koczot, K.M., Jeton, A.E., McGurk, B.J., and Dettinger, M.D., 2004, Precipitation-runoff processes in the Feather River Basin, northeastern California, with prospects for streamflow predictability, water years 1971-97: U.S. Geological Survey Scientific Investigations Report 2004-5202, 82 p.

Kuhn, G., 1989, Application of the U.S. Geological Survey's precipitation-runoff modeling system to Williams Draw and Bush Draw Basins, Jackson County, Colorado: U.S. Geological Survey Water-Resources Investigations Report 88-4013, 38 p.

Laenen, A., and Risley, J.C., 1997, Precipitation-runoff and streamflow-routing models for the Willamette River Basin, Oregon: U.S. Geological Survey Water-Resources Investigations Report 95-4284, 197 p.

Leavesley, G.H., Lichty, R.W., Troutman, B.M., and Saindon, L.G., 1983, Precipitation-runoff modeling system-User's manual: U.S. Geological Survey Water-Resources Investigations Report 83-4238, 207 p.

Leavesley, G.H., Markstrom, S.L., Brewer, M.S., and Viger, R.J., 1996, The modular modeling system (MMS)—The physical process modeling component of a database-centered decision support system for water and power management: Water, Air, and Soil Pollution, v. 90, nos. 1-2, p. 303-311.

Leavesley, G.H., Markstrom, S.L., Viger, R.J., and Hay, L.E., 2005, U.S. Geological Survey Modular Modeling System (MMS) Precipitation-Runoff Modeling System (PRMS) (MMS-PRMS), in Singh, V., and Frevert, D., eds., Watershed Models: Boca Raton, Fla., CRC Press, p. 159-177.

Leavesley, G.H., Restrepo, P.J., Markstrom, S.L., Dixon, M., and Stannard, L.G., 1996, The modular modeling system (MMS)_User's Manual: U.S. Geological Survey OpenFile Report 96-151, 200 p.

Loveland, T.R., Merchant, J.W., Ohlen, D.O., and Brown, J.F., 1991, Development of a land-cover characteristics database for the conterminous United States: Photogrammetric Engineering and Remote Sensing, v. 57, no. 11, p. 1453-1463.

Maine Atlantic Salmon Commission, 2005, ATS 2015: Maine Atlantic Salmon Commission's 10-year strategic plan: November 29, 2005, 34 p. 
Maine Atlantic Salmon Task Force, 1997, Atlantic salmon conservation plan for seven Maine rivers: March 1997, $303 \mathrm{p}$.

Maine Office of Geographic Information Systems (MEGIS), 2006, Maine Land-Cover Dataset (MELCD) accessed June 21, 2006, at http://megis.maine.gov/catalog/.

Markstrom, S.L., and Hay, L.E., 2009, Integrated watershed scale response to climate change for selected basins across the United States: Water Resources Impact, v. 11, no. 2, p. 8-10.

Markstrom, S.L., Niswonger, R.G., Regan, R.S., Prudic, D.E., and Barlow, P.M., 2008, GSFLOW-Coupled groundwater and surface-water flow model based on the integration of the Precipitation-Runoff Modeling System (PRMS) and the Modular Groundwater Flow Model (MODFLOW-2005): U.S. Geological Survey Techniques and Methods 6-D1, $240 \mathrm{p}$.

Mastin, M.C., and Vaccaro, J.J., 2002, Watershed models for decision support in the Yakima River Basin: U.S. Geological Survey Open-File Report 02-404, 46 p.

Moriasi, D.N., Arnold, J.G., Van Liew, M.W., Bingner, R.L., Harmel, R.D., and Veith, T.L., 2007, Model evaluation guidelines for systematic quantification of accuracy in watershed simulations: Transactions of the American Society of Agricultural and Biological Engineers, v. 50, no. 3, p. 885-900.

Nash, J.E., and Sutcliffe, J.V., 1970, River flow forecasting through conceptual models: Part 1-A discussion of principles: Journal of Hydrology, v. 10, no. 3, p. 282-290.

National Marine Fisheries Service and U.S. Fish and Wildlife Service, 2004, Draft recovery plan for the Gulf of Maine Distinct Population Segment of Atlantic Salmon (Salmo Salar): National Marine Fisheries Service, Silver Spring, Md., 325 p.

National Oceanic and Atmospheric Administration, 2002, Climatography of the United States no. 81, monthly station normals of temperature, precipitation, and heating and cooling degree days, 1971-2000: Region 17, Maine, 16 p.

National Oceanic and Atmospheric Administration, 2009, Designation of critical habitat for Atlantic salmon (Salmo salar) Gulf of Maine Distinct Population Segment-Final rule: Code of Federal Regulations Part 226, Endangered and Threatened Species, Federal Register Volume 74, Number 117, June 19, 2009, 43 p.

National Oceanic and Atmospheric Administration Cooperative Observer Program, 2010, United States National Weather Service database accessed April 2010, at http://www.nws.noaa.gov/om/coop/.
Olson, S.A., 2002, Flow-frequency characteristics of Vermont streams: U.S. Geological Survey Water-Resources Investigations Report 02-4238, 46 p.

Parker, R.S., and Norris, J.M., 1989, Simulation of streamflow in small drainage basins in the southern Yampa River Basin, Colorado: U.S. Geological Survey Water-Resources Investigations Report 88-4071, 47 p.

Randall, A.D., 1996, Mean annual runoff, precipitation, and evapotranspiration in the glaciated northeastern United States, 1951-80: U.S. Geological Survey Open-File Report 96-395, 2 sheets.

Randall, A.D., 2000, Hydrogeologic framework of stratifieddrift aquifers in the glaciated northeastern United States: U.S. Geological Survey Professional Paper 1415-B, 179 p. (plate showing hydrophysiographic regions in the glaciated northeastern United States, scale 1:2,500,000).

Rantz, S.E., and others, 1982, Measurement and computation of streamflow: U.S. Geological Survey Water-Supply Paper 2175, v. 2, 631 p.

Scott, A.G., 1984, Analysis of characteristics of simulated flows from small surface-mined and undisturbed Appalachian watersheds in the Tug Fork Basin of Kentucky, Virginia, and West Virginia: U.S. Geological Survey WaterResources Investigations Report 84-4151, 169 p.

Thompson, W.B., and Borns, H.W., 1985, Surficial geologic map of Maine: Maine Geological Survey, Department of Conservation, scale 1:5,000,000, 1 sheet.

Thompson, W.B., Crossen, K.J., Borns, H.W., Jr., and Andersen, B.G., 1983, Glacial-marine deltas and late Pleistocene-Holocene crustal movements in southern Maine: Maine Geological Survey Open-File Report 83-3, 18 p.

Umemoto, M., Hay, L.E., Markstrom, S.L., and Leavesley, G.H., 2006, Luca: a wizard-style graphical user interface for easy and systematic multi-objective, stepwise calibration of hydrologic models: Joint 8th Federal Interagency Sedimentation Conference and 3d Federal Interagency Hydrologic Modeling Conference, April 2-6, 2006, Reno, Nev., 8 p.

U.S. Department of Agriculture, 1994, State soil geographic (STATSGO) data base - data use information: U.S. Department of Agriculture Miscellaneous Publication Number $1492,113 \mathrm{p}$.

U.S. Department of Agriculture, 2005, Forests of Maine, 2003: Northeastern Forest Inventory and Analysis, 104 p.

U.S. Geological Survey, 2005, Landsat: A global land imaging project: U.S. Geological Survey Fact Sheet 023-03, 4 p. 
U.S. Geological Survey, 2008, The National Map Seamless Server, accessed July 2008, at http://seamless.usgs.gov/.

U.S. Geological Survey, 2009, MMS PRMS Documentation, accessed October 6, 2009, at http://wwwbrr.cr.usgs.gov/ projects/SW_MoWS/software/oui_and_mms_s/ prms page.shtml.

Viger, R.J., and Leavesley, G.H., 2007, The GIS Weasel user's manual: U.S. Geological Survey Techniques and Methods, book 6, chap. B4, 201 p.

Ward-Garrison, C., Markstrom, S.L., and Hay, L.E., 2009, Downsizer-A graphical user interface-based application for browsing, acquiring, and formatting time-series data for hydrologic modeling: U.S. Geological Survey Open-File Report 2009-1166, 27 p.

Zhu, Z., 1994, Forest density mapping in the lower 48 statesA regression procedure: U.S. Department of Agriculture, Forest Service, Southern Forest Experiment Station, Research Paper SO-280, 11 p.

Zhu, Z., and Evans, D.L., 1994, U.S. forest type groups and predicted percent forest cover from advanced very-highresolution radiometer (AVHRR) data: Photogrammetric Engineering and Remote Sensing, v. 60, no. 5, p. 525-531. 
Prepared by the Pembroke and Lafayette Publishing Service Centers.

For more information concerning this report, contact:

Director

U.S. Geological Survey

Maine Water Science Center

196 Whitten Road

Augusta, ME 04330

dc_me@usgs.gov

or visit our Web site at:

http://me.water.usgs.gov 
